\title{
A California Statewide Three-Dimensional Seismic Velocity Model from Both Absolute and Differential Times
}

\author{
by Guoqing Lin, ${ }^{*}$ Clifford H. Thurber, Haijiang Zhang, ${ }^{\dagger}$ Egill Hauksson, Peter M. Shearer, \\ Felix Waldhauser, Thomas M. Brocher, and Jeanne Hardebeck
}

\begin{abstract}
We obtain a seismic velocity model of the California crust and uppermost mantle using a regional-scale double-difference tomography algorithm. We begin by using absolute arrival-time picks to solve for a coarse three-dimensional (3D) $P$ velocity $\left(V_{P}\right)$ model with a uniform $30 \mathrm{~km}$ horizontal node spacing, which we then use as the starting model for a finer-scale inversion using double-difference tomography applied to absolute and differential pick times. For computational reasons, we split the state into 5 subregions with a grid spacing of 10 to $20 \mathrm{~km}$ and assemble our final statewide $V_{P}$ model by stitching together these local models. We also solve for a statewide $S$-wave model using $S$ picks from both the Southern California Seismic Network and USArray, assuming a starting model based on the $V_{P}$ results and a $V_{P} / V_{S}$ ratio of 1.732. Our new model has improved areal coverage compared with previous models, extending $570 \mathrm{~km}$ in the SW-NE direction and $1320 \mathrm{~km}$ in the NW-SE direction. It also extends to greater depth due to the inclusion of substantial data at large epicentral distances. Our $V_{P}$ model generally agrees with previous separate regional models for northern and southern California, but we also observe some new features, such as high-velocity anomalies at shallow depths in the Klamath Mountains and Mount Shasta area, somewhat slow velocities in the northern Coast Ranges, and slow anomalies beneath the Sierra Nevada at midcrustal and greater depths. This model can be applied to a variety of regional-scale studies in California, such as developing a unified statewide earthquake location catalog and performing regional waveform modeling.
\end{abstract}

Online Material: Smoothing and damping trade-off analysis, a priori Moho depth, resolution tests, and map-view slices and cross sections through the $3 \mathrm{D} V_{P}$ and $V_{S}$ models.

\section{Introduction}

Numerous studies of velocity structure in California have been done with varying scales in different areas (Table 1). The largest and most complete crustal tomography models in California are the recent southern California model by Lin et al. (2007) and the northern California model by Thurber et al. (2009). These studies have revealed key features of the crustal structure of California. The integration of the Northern and Southern California Seismic Networks (NCSN and SCSN) into a unified statewide network, the California Integrated Seismic Network (CISN; e.g., Hellweg et al., 2007), has motivated the development of a statewide seismic velocity

\footnotetext{
*Now at Division of Marine Geology and Geophysics, Rosenstiel School of Marine and Atmospheric Science, University of Miami, Miami, Florida, 33149 (glin@rsmas.miami.edu).

Also at Department of Geoscience, University of Wisconsin-Madison, 1215 W. Dayton St., Madison, Wisconsin 53706.
}

model for locating earthquakes in California. In this study, we take advantage of the regional-scale double-difference (DD) tomography algorithm (Zhang and Thurber, 2006) to develop $P$ - and $S$-wave velocity models for the entire state of California. Our $P$ velocity model is derived from both first-arrival absolute and differential time picks obtained from the California seismic networks and has a horizontal grid spacing as fine as $10 \mathrm{~km}$. The $S$ velocity model is solved using the SCSN and USArray picks with a horizontal grid spacing of $30 \mathrm{~km}$. There are numerous tomographic studies in California and it is impractical to compare our model with all of them; we focus on a comparison with the recent regional-scale tomographic studies for southern and northern California by Lin et al. (2007) and Thurber et al. (2009). Because our $V_{P}$ and $V_{S}$ models are solved using different sets of data and the $V_{P}$ model has better resolution, we present 


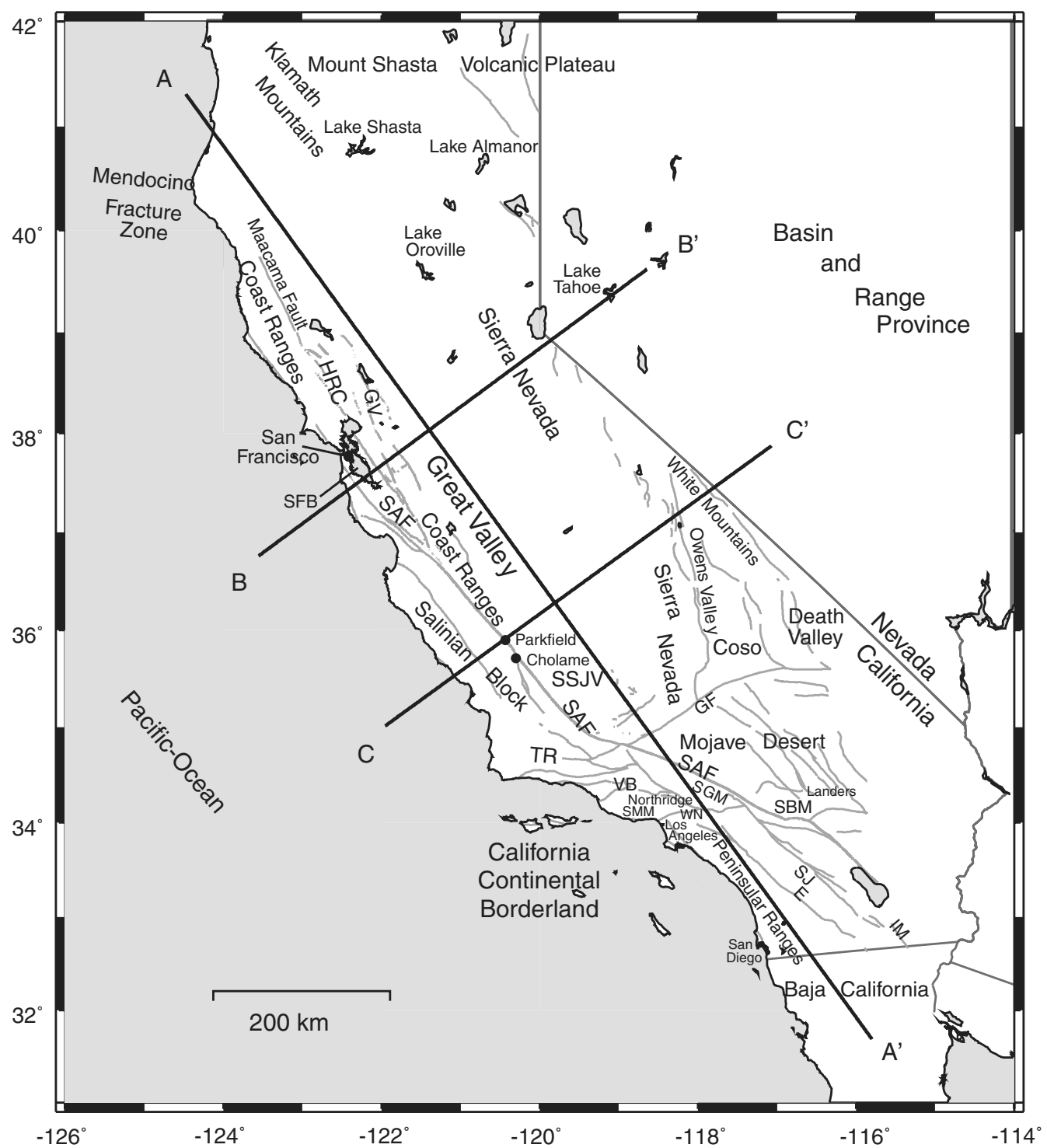

Figure 1. Map of selected geological and geographic features in our study area. The thick straight lines indicate the model cross sections shown in Figure 7. The NW-SE profile A-A' is parallel to the San Andreas fault, and the SW-NE profiles B-B' and C-C' are perpendicular to the San Andreas fault. Abbreviations: E, Elsinore fault; GF, Garlock fault; GV, Green Valley fault; HRC, Healdsburg-Rodgers Creek fault; IM, Imperial Valley fault; SAF, San Andreas fault; SBM, San Bernardino Mountains; SFB, San Francisco Bay; SGM, San Gabriel Mountains; SJ, San Jacinto fault; SMM, Santa Monica Mountains; SSJV, Southern San Joaquin Valley; TR, Transverse Ranges; VB, Ventura basin; WN, Whittier Narrows.

them separately with more emphasis on the $V_{P}$ model. Figure 1 shows selected geological and geographic features in our study and the positions of three profiles for the velocity cross sections.

\section{$P$-Wave Velocity Model}

\section{Data and Inversion Method}

The data sets for our $V_{P}$ model are the first-arrival absolute and differential times of 8720 earthquakes recorded by the seismic networks in California, consisting of 4325 events from the Northern California Seismic Network,
3668 events from the Southern California Seismic Network, and 727 events from the Pacific Gas and Electric seismic network (blue, pink, and green dots in Fig. 2a, respectively). These earthquakes were selected based on having the greatest number of $P$ picks among those events within a $6 \mathrm{~km}$ radius, with a magnitude threshold of 2.5 . The total number of $P$ picks in our data set is 551,318 with an average of 63 picks per event. In order to improve constraints on the shallow crustal structure, we assembled first-arrival times from 3110 explosions and airguns (red circles in Fig. 2b) recorded on profile receivers and network stations. The principal active-source data sets and sources are listed in Table 2 . 
(a)

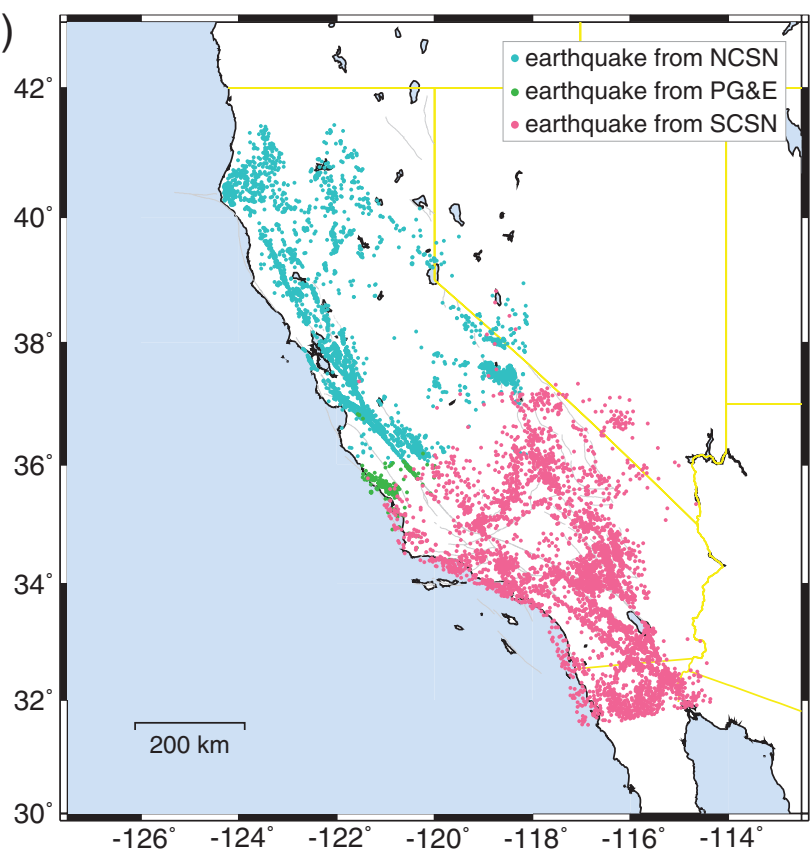

(c)

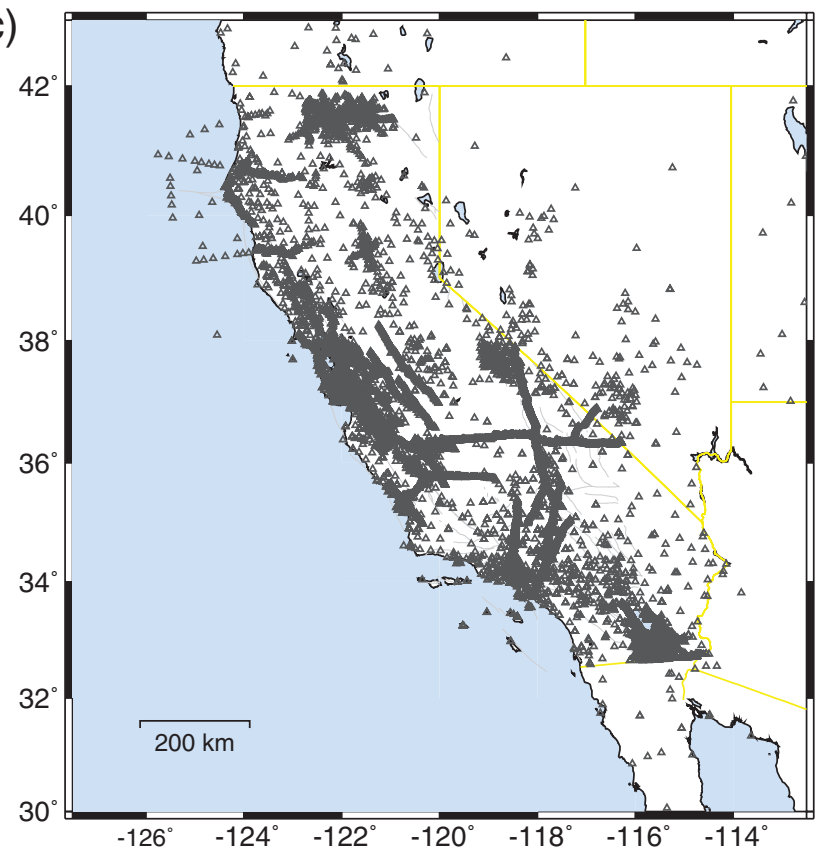

(b)

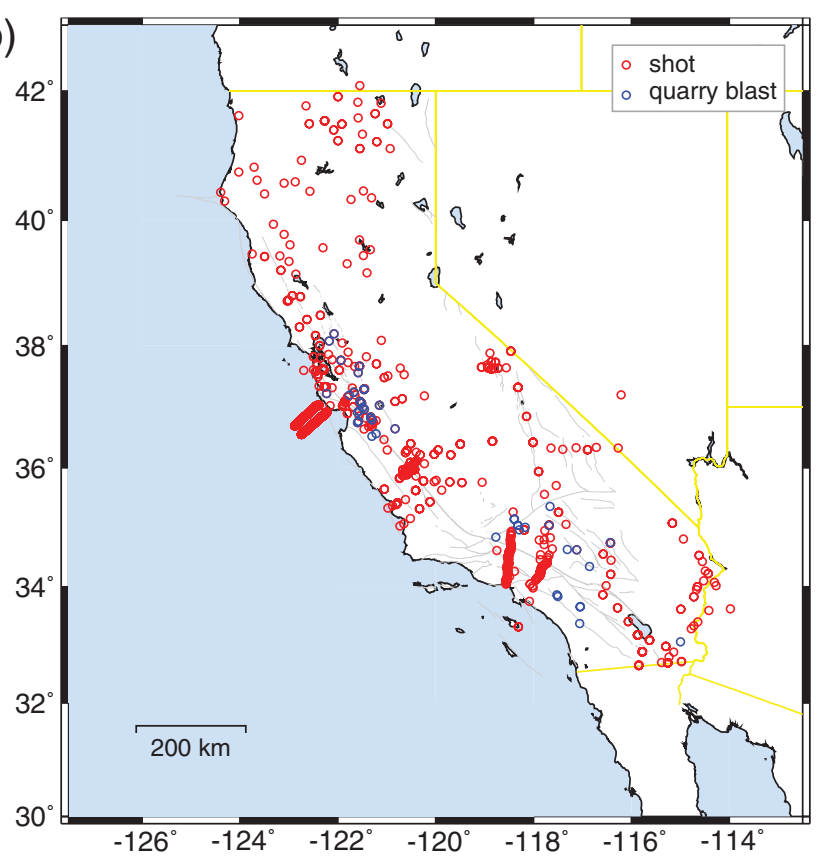

(d)

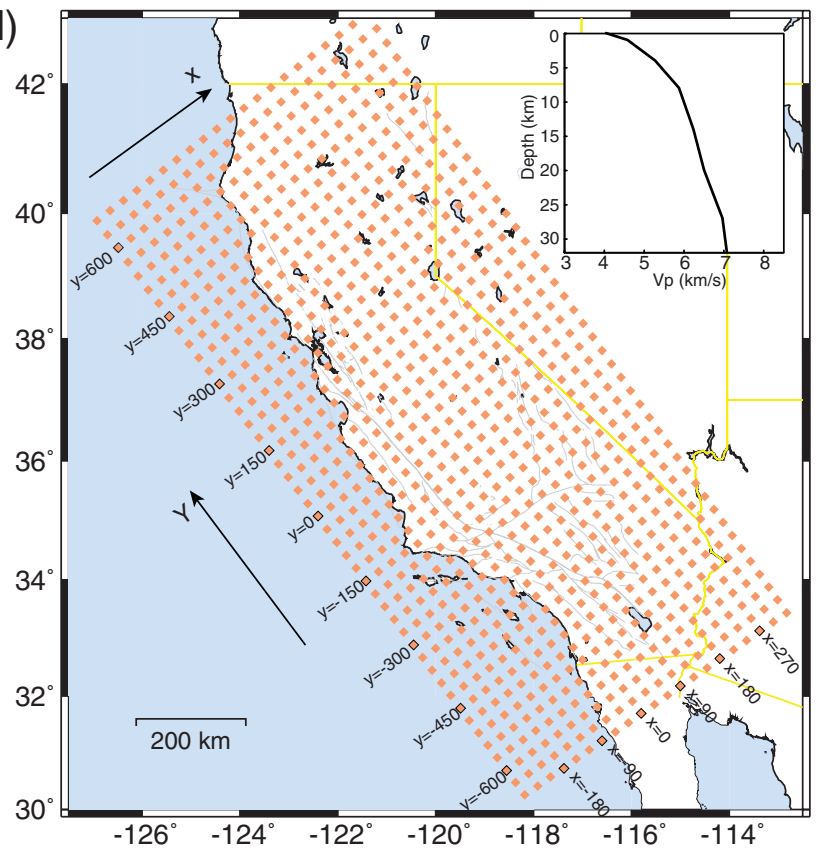

Figure 2. Event and station distributions in our study area and starting inversion grid nodes for the 3D coarse model (30-km horizontal spacing). (a) earthquakes; (b) controlled sources; (c) stations; (d) inversion grid nodes (small panel shows the 1D starting velocity model).

Quarry blasts, which have known locations but unknown origin times, are also valuable to be included in tomographic inversions because they provide constraints that are almost as good as the active-source data. We include data from 44 quarry blasts (blue circles in Fig. 2b), with 19 in southern California (see Lin et al., 2007) and 25 in northern California. Figure $2 \mathrm{c}$ shows the locations of temporary and network stations used in our study.

The model presented in this study is obtained by using a regional-scale DD tomography algorithm (tomoFDD; Zhang and Thurber, 2006), which is a generalization of DD location (Waldhauser and Ellsworth, 2000). It maps a sphericalEarth coordinate system into a Cartesian coordinate system (a sphere in a box; Flanagan et al., 2007) and incorporates a finite-difference travel time calculator and spatial smoothing constraints. This algorithm is designed to solve jointly for 3D velocity structure and earthquake locations using both firstarrival times and differential times, leading to improved resolution in the seismically active areas where the differential data provide dense sampling. 
Table 1

A Subset of the Previous Studies on Seismic Velocity Structure in California

\begin{tabular}{ll}
\hline \multicolumn{1}{c}{ Study Area } & \multicolumn{1}{c}{ References } \\
\hline Coalinga & Eberhart-Phillips (1990) \\
Coast Ranges & Eberhart-Phillips (1986); Henstock et al.(1997); Bleibinhaus et al.(2007) \\
Coso geothermal area & Hauksson and Unruh (2007) \\
Coyote Lake & Thurber (1983) \\
Great Valley & Hwang and Mooney (1986); Godfrey et al. (1997) \\
Greater Los Angeles basin & Magistrale et al. (1996); Hauksson and Haase (1997); Lutter et al. (1999) \\
Loma Prieta & Foxall et al. (1993); Thurber et al. (1995); Eberhart-Phillips and Michael (1998) \\
Monterey Bay & Begnaud et al. (2000) \\
Parkfield region & Eberhart-Phillips and Michael (1993); Thurber et al. (2003, 2006) \\
San Francisco Bay region & Manaker et al. (2005); Hardebeck et al. (2007); Thurber et al (2007) \\
Santa Monica Mountains & Lutter et al. (2004) \\
Sierra Nevada arc & Brocher et al. (1989); Fliedner et al. (1996, 2000); Boyd et al. (2004) \\
Entire southern California & Hauksson (2000); Huang and Zhao (2003); Zhou (2004) \\
\hline
\end{tabular}

\section{D Coarse Model}

Because of the large spatial scale and amount of data in our study, we first solve for a coarse 3D $V_{P}$ model starting with a one-dimensional (1D) velocity model (shown in the small panel of Fig. 2d) for the entire state. This 1D model is based on standard regional $1 \mathrm{D}$ velocity models used to locate earthquakes by the seismic networks in northern and southern California. The starting model nodes (shown in Fig. 2d) are uniformly spaced at $30 \mathrm{~km}$ intervals in the horizontal directions and extend $570 \mathrm{~km}$ in the SW-NE direction and $1320 \mathrm{~km}$ in the NW-SE direction. In the vertical direction, the nodes are positioned at $-1,1,4,8,14,20,27$, 35 , and $45 \mathrm{~km}$ (relative to mean sea level). We only use absolute arrival times for this 3D coarse model. An a priori Moho is not included at this stage, but is introduced later for the finer-scale model. Preliminary inversions were carried out using the tomography algorithm simul2000 (Thurber and Eberhart-Phillips, 1999). This algorithm simultaneously solves for 3D velocity structure and earthquake locations using the first-arrival times employing an iterative dampedleast-squares method. This step was taken for data quality control purposes (i.e., identifying poorly constrained events and picks with very high residuals), and to provide formal but approximate estimates of velocity model resolution and uncertainty. After the data quality control step using simul2000, we applied the regional-scale DD tomography algorithm, which is more suitable for the large-scale area

Table 2

Active-Source Data Sets Included in the Statewide Tomographic Inversion

\begin{tabular}{|c|c|c|c|c|}
\hline Experiment Name & Reference & Year & No. Shots & No. Stations \\
\hline USGS & Warren (1978) & 1967 & 9 & 147 \\
\hline Geysers-San Pablo Bay & Warren (1981) & 1976 & 5 & 135 \\
\hline Oroville & Spieth et al. (1981) & 1977 & 5 & 118 \\
\hline Imperial Valley & Kohler and Fuis (1988) & 1979 & 41 & 932 \\
\hline Western Mojave Desert & Harris et al.(1988) & 1980 & 10 & 245 \\
\hline Gilroy-Coyote Lake & Mooney and Luetgert (1982) & $1980 / 1981$ & 4 & 236 \\
\hline Livermore & Williams et al. (1999) & $1980 / 1981$ & 3 & 251 \\
\hline Great Valley & Murphy (1989); Colburn and Walter (1984) & $1981 / 1982$ & 7 & 221 \\
\hline San Juan Bautista & Mooney and Colburn (1985) & $1981 / 1982$ & 6 & 335 \\
\hline Shasta 1981 & Kohler et al. (1987) & 1981 & 1 & 274 \\
\hline Shasta 1982 & Kohler et al. (1987) & 1982 & 9 & 299 \\
\hline Morro Bay & Murphy and Walter (1984) & 1982 & 9 & 230 \\
\hline Coalinga & Murphy and Walter (1984) & 1983 & 9 & 209 \\
\hline Long Valley & Meador et al. (1985) & 1983 & 9 & 278 \\
\hline San Luis Obispo & Sharpless and Walter (1988) & 1986 & 10 & 123 \\
\hline Loma Prieta & Brocher et al. (1992) & 1990 & 2252 & 16 \\
\hline San Francisco Bay 1991 & Murphy et al.(1992); Kohler and Catchings (1994); Brocher and Pope (1994) & 1991 & 6 & 300 \\
\hline PACE 1992 & Fliedner et al. (1996) & 1992 & 5 & 384 \\
\hline Southern Sierra & Fliedner et al. (1996) & 1993 & 23 & 1241 \\
\hline San Francisco Bay 1993 & Catchings et al. (2004) & 1993 & 14 & 399 \\
\hline LARSE 1994 & Murphy et al. (1996) & 1994 & 125 & 889 \\
\hline LARSE 1999 & Fuis, Murphy,et al. (2001) & 1999 & 78 & 925 \\
\hline Parkfield & Thurber et al. (2003, 2004); Hole et al. (2006) & 2003 & 157 & 242 \\
\hline Network & Northern and Southern California Earthquake Data Center & $1976-2003$ & 270 & 659 \\
\hline
\end{tabular}


in this study. To make the inversion more stable, some regularization method is required, such as smoothing and damping. Smoothing regularization provides a minimumfeature model that contains only as much structure as can be resolved above the estimated level of noise in the data (Zhang and Thurber, 2003). Damping and smoothing are often selected empirically, by running a series of singleiteration inversions with a large range of values, and plotting the data variance versus model variance trade-off curves (e.g., Eberhart-Phillips, 1986, 1993). We explored a wide range of damping (from 25 to 1000) and smoothing (from 0 to 1000) to make sure that we looked at the entire trade-off curve instead of a portion of it. The smoothing constraint weighting of 100 (same for the horizontal and vertical directions) and the damping parameter of 350 were chosen by examining these trade-off curves, which produced good compromises between data misfit and model variance (see (E) Figure $\mathrm{S} 1$ in the electronic edition of $B S S A$ ).

\section{D Starting Model Adjustments}

Our preliminary modeling work did not include an $a$ priori velocity increase at the Moho, but first-arrival bodywave tomography by itself was not capable of imaging sharp discontinuities. Thus, after we obtained the 3D coarse velocity model, we introduced an a priori Moho interface (see (E) Figure S2 in the electronic edition of BSSA) from the results of Fuis and Mooney (1990), which was a modification of Mooney and Weaver (1989). We set the velocity to $8 \mathrm{~km} / \mathrm{sec}$ in the model layer right below the Moho and $8.2 \mathrm{~km} / \mathrm{sec}$ at the deepest layer with a linear gradient for the layers between these two layers. In order to start with a conservative 3D model, we removed the low-velocity anomalies in the 3D coarse model, that is, we require that velocity is initially a monotonically increasing function of depth. The resulting adjusted 3D model is the starting model for our final $P$ velocity model. Figure 3a shows the map view of this model at $4 \mathrm{~km}$ depth, with the layer-average velocity values in the inset of Figure $3 \mathrm{~b}$. In order to check the effects of the inclusion of the Moho interface on our final results, we compared our final model with a model obtained without a Moho (lowvelocity anomalies are still removed). The two models are quite similar over well-resolved areas and the model differences between the initial models are reduced after the inversion, indicating that our process converges. (E) Table $\mathrm{S} 1$ in the electronic edition of BSSA shows a comparison of models with and without the inclusion of a Moho interface.

In order to use differential times to obtain a finer-scale model given our computer memory limitations, we split the entire state into five subregions (Fig. 3a). The adjacent subregions overlap by about $30 \mathrm{~km}$. We use the same depth layers as the coarse model. Figure $3 \mathrm{~b}$ shows the event and station distributions for subregion 1 as an example. For each subregion inversion, we use absolute and differential times from events inside the subregion (blue circles in Fig. 3b) that are recorded by all the stations (black triangles) and only absolute times from events outside of the subregion (pink circles) that are recorded by stations inside of the subregion. In this way, we improved the resolution of the resulting velocity model for (a)

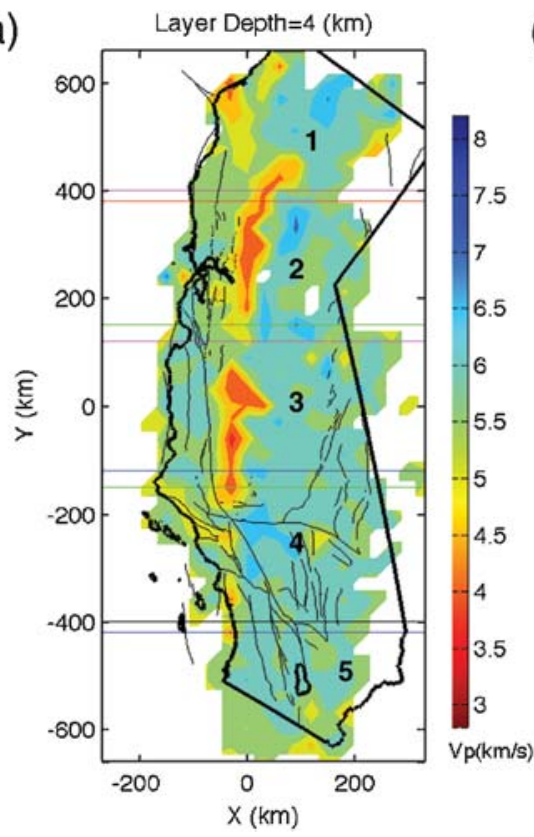

(b) 4

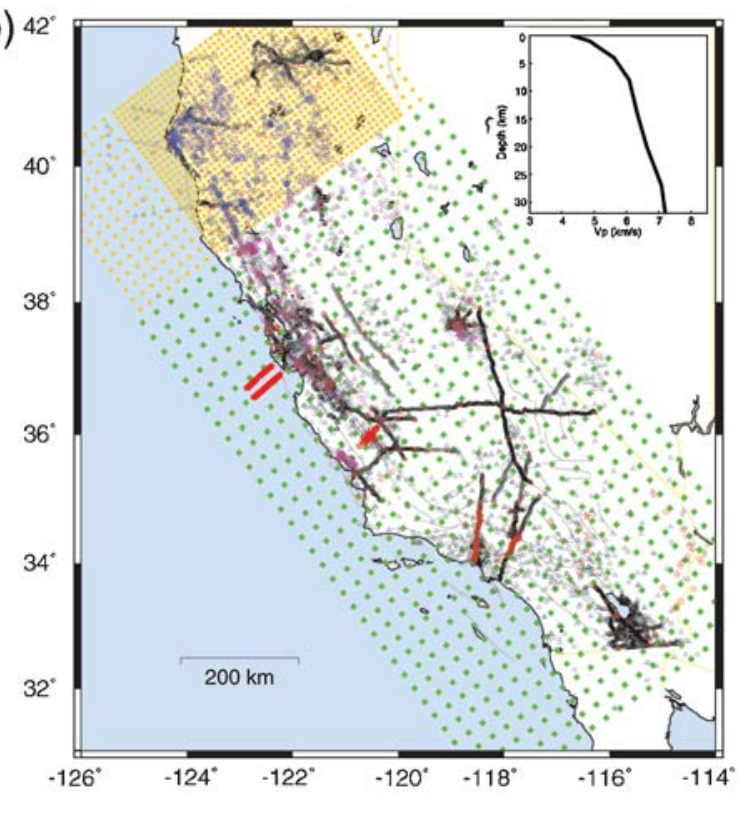

Figure 3. (a) Map view of the 3D coarse velocity model at $4 \mathrm{~km}$ depth and the boundaries of the 5 subregions. (b) Event and station distribution in the subregion 1 (small panel shows the 1D layer-average velocity). Yellow squares: finer inversion nodes inside of subregion; green squares: nodes with fixed velocities; blue circles: earthquakes inside of subregion 1; pink circles: earthquakes outside of subregion 1 but recorded by stations inside of the subregion; black triangles: permanent and temporary stations; red stars: active sources (shots and quarry blasts). Please refer to the text for more details. 
the deeper layers due to the inclusion of substantial data at large epicentral distances. We also include all available explosion and quarry data for each subregion (red stars). Inside of each subregion, the horizontal nodes are spaced at $10 \mathrm{~km}$ intervals in the areas with dense data coverage and $20 \mathrm{~km}$ in other areas (yellow squares). The node spacing outside of each subregion is $30 \mathrm{~km}$ from the coarse model (green squares). The initial velocity value at each node is computed from the velocity values at the surrounding eight nodes of the coarse initial model using trilinear interpolation as described in Thurber and Eberhart-Phillips (1999). The velocities outside of each subregion are fixed during the inversion of the inside-subregion velocities. We inverted five local models separately; our final statewide velocity model is a stitched version of all the five subregion models. The velocities in the areas of overlap are computed as the average velocities of the two adjacent subregions. In order to test the robustness of our stitching approach, we inverted a model that includes subregions 1 and 2 and compared the resulting model with the stitched model. The two models are quite similar with some minor differences that are likely caused by different regularization parameters, which are determined individually for each inversion by examining data variance versus model variance trade-off curves.

\section{Model Quality and Resolution}

The quality of our model can be evaluated by its ability to (1) fit the observed arrival-time data, and (2) produce accurate locations for onland controlled-source explosions that have known coordinates. Figure 4 shows a comparison of the arrival-time residual distribution before (a) and after the coarse (b) and final (stitched) (c) 3D velocity inversions for the entire data set (including controlled sources). The root-mean-square (rms) misfit is reduced by over a factor of 3 , from $1.26 \mathrm{sec}$ to $0.37 \mathrm{sec}$, after the $3 \mathrm{D}$ coarse model inversion, and then to $0.32 \mathrm{sec}$ after the final model inversion. The reason that the fit to absolute times in the subregion model inversions is only slightly better than the coarse model fit is because the purpose of this step is to improve fine-scale velocity resolution by using differential times. A hierarchical weighting scheme is applied with greater weight to the absolute data for the first two iterations and greater weight to the differential data for the next four iterations. Note that most of the improvement of arrival-time fit after the 3D final model inversion is mainly due to the lower differential time residuals, where the rms misfit of the differential times is reduced from $0.28 \mathrm{sec}$ to $0.11 \mathrm{sec}$.

We independently located the onshore explosions using the starting $1 \mathrm{D}$ and the coarse and final 3D velocity models and then calculated the horizontal and vertical location differences between the relocations and the known true locations. Figure 5 shows histograms of shot location accuracy relocated using the starting $1 \mathrm{D}$ model compared with the two 3D models for both horizontal and vertical coordinates. The horizontal location errors are all positive; the vertical errors
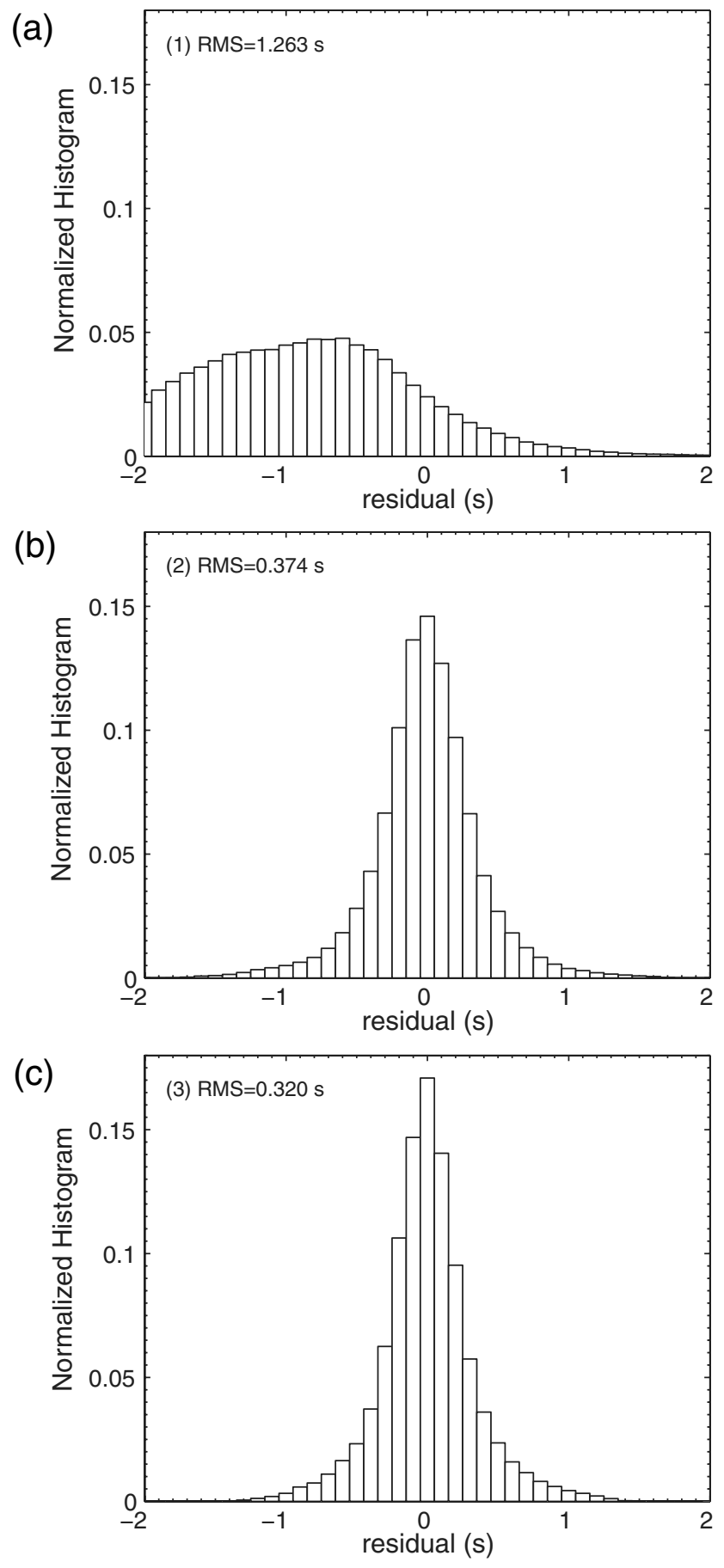

Figure 4. The arrival-time residual distribution for the entire data set (including controlled sources) (a) before 3D velocity inversion; (b) after 3D coarse model inversion; (c) after 3D final model inversion.

are positive when the assigned location is deeper than the true location and negative when the assigned location is shallower than the true location. For the 1D model, the error distributions are quite broad, with a mean error of $1.23 \mathrm{~km}$, and a standard deviation of $1.08 \mathrm{~km}$ horizontally. The vertical error distribution has peaks at about 0.6 and $4.5 \mathrm{~km}$, a mean (absolute) error of $2.19 \mathrm{~km}$, and a standard deviation of 
(a)

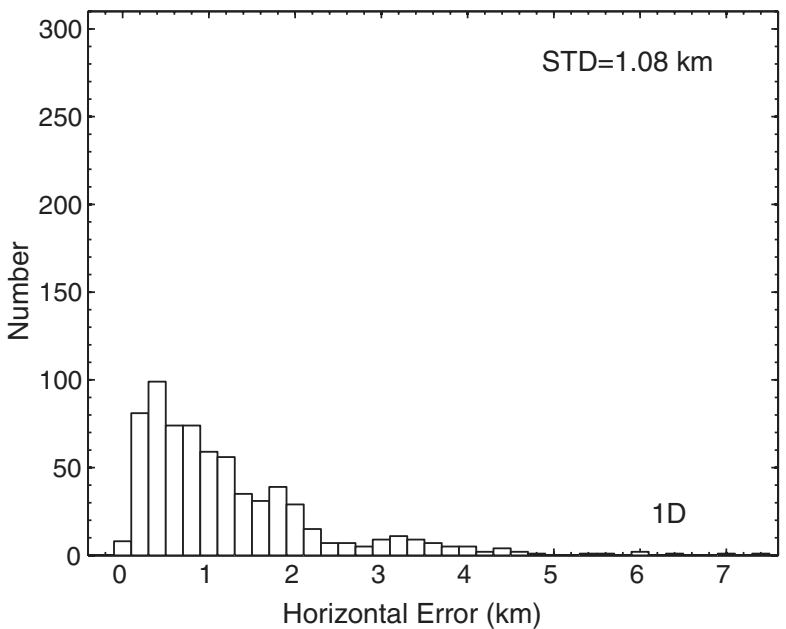

(c)

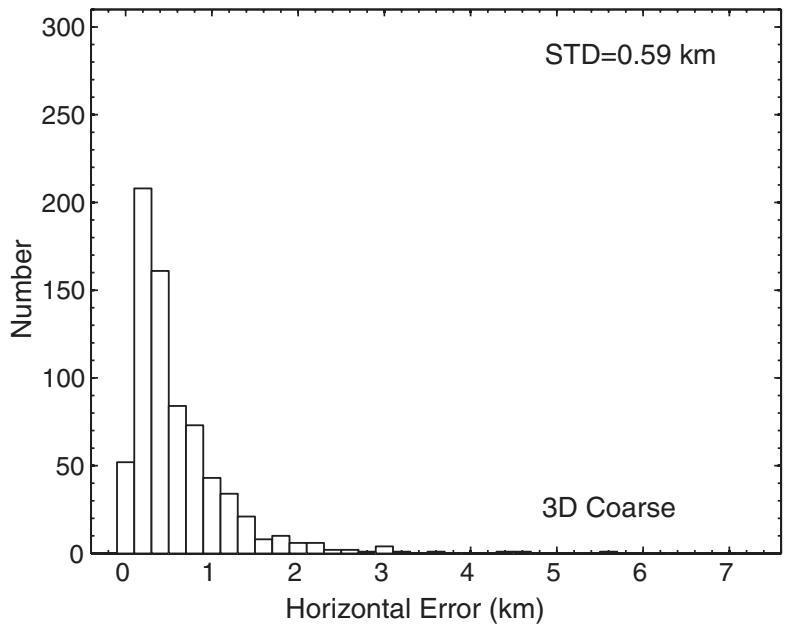

(e)

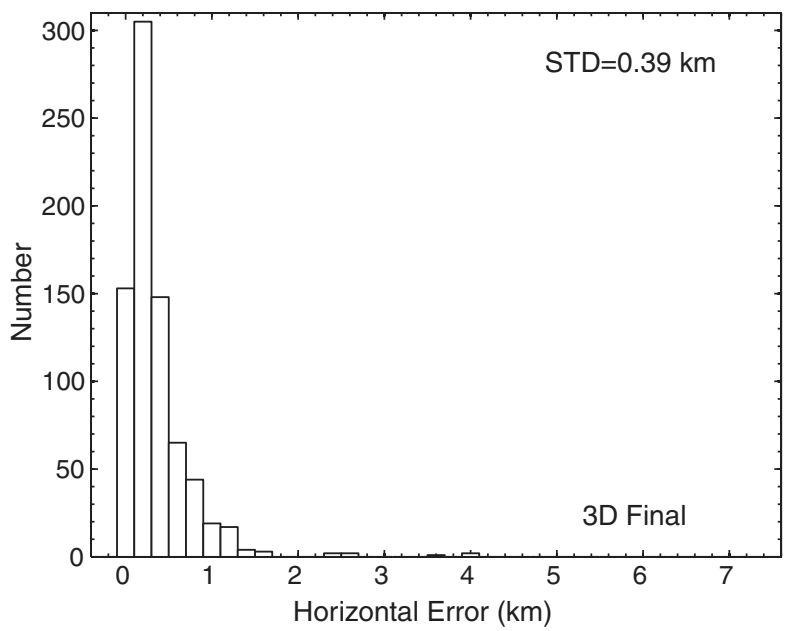

(b)

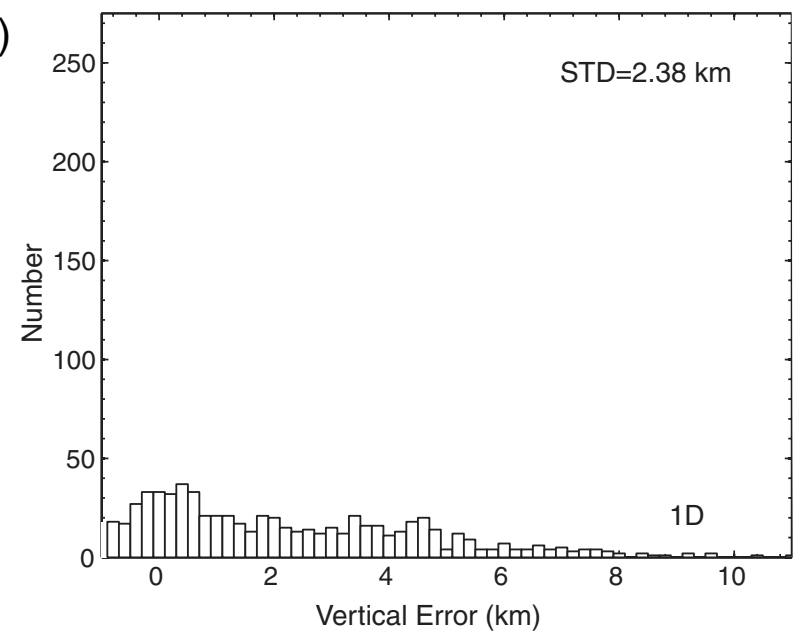

(d)

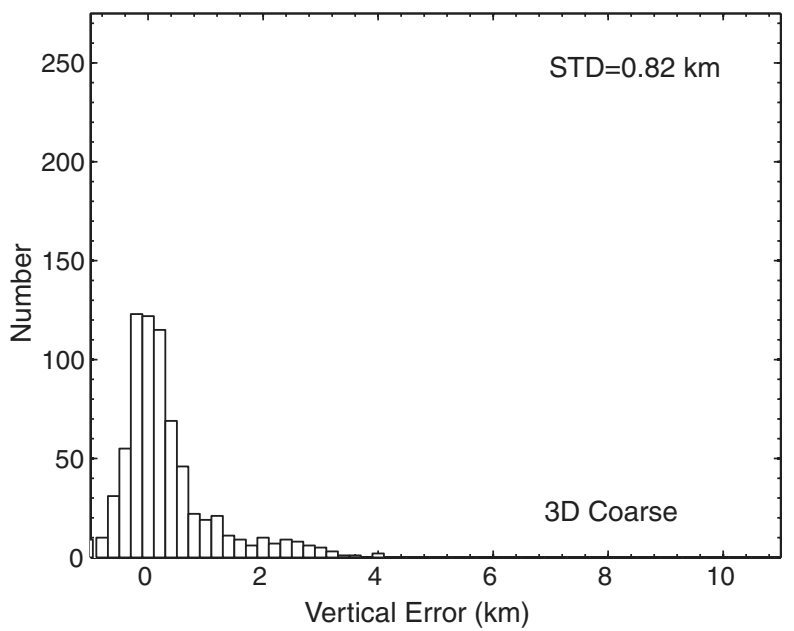

(f)

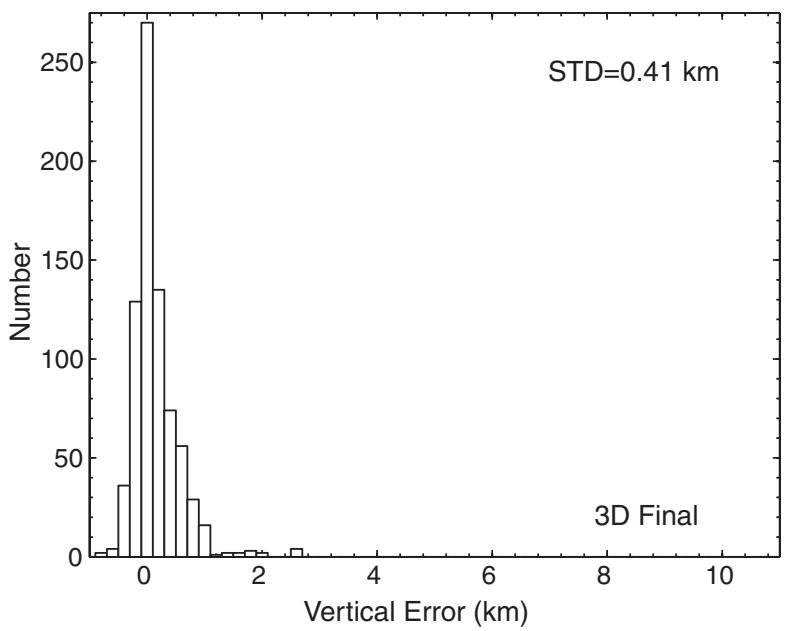

Figure 5. Histograms of the differences between relocations and known true locations for onland explosions. The two columns are for horizontal and vertical location errors, respectively. (a) and (b) 1D model; (c) and (d) 3D coarse model; (e) and (f) 3D final model.

$2.38 \mathrm{~km}$. In contrast, the 3D coarse model error distributions are peaked between 0 and $1 \mathrm{~km}$, with mean errors of 0.60 and $0.32 \mathrm{~km}$, and standard deviations of 0.59 and $0.82 \mathrm{~km}$ for the horizontal and vertical errors, respectively. Although this model is coarse, the $3 \mathrm{D}$ shot relocations are significantly improved, especially in depth. This is because a single
1D-velocity model cannot account for lateral heterogeneity in velocity structure across all of California. Further, the $3 \mathrm{D}$ final model location error distributions are peaked around $0.2 \mathrm{~km}$, with mean errors of 0.35 and $0.15 \mathrm{~km}$ and standard deviations of 0.39 and $0.41 \mathrm{~km}$ for the horizontal and vertical errors, respectively. The poorly located shots fall into several 
categories. One group is distant shots recorded on permanent network stations for cases in which we were not able to obtain the corresponding refraction profile picks. An example is the shots from the PACE 1992 project (Fliedner et al., 1996). Others are cases for which data for a particular shot were split into two separate events, due to the fact that the data were obtained and entered into the database separately. Examples are a number of shots from the Parkfield area and several LARSE shots. Finally, there are a few shots for which only profile picks are available, and the recording geometry is too poor to constrain the locations adequately. The reduction in relocation errors of about a factor of 2 over the 3D coarse model indicates that our final model significantly improves resolution for the lateral heterogeneities in the 3D velocity structure, especially at shallow depths.

To assess the model quality, we performed a restoration and a checkerboard resolution test similar to those in Thurber et al. (2009). In the restoration test, event hypocenters, station locations, and synthetic travel times, calculated from the final inverted model, have the same distribution as the real data. We followed the same inversion strategies as those for the real data and examined the recovering ability of our algorithms. The inverted final model is similar to the true model over well-resolved areas (see (E) Figure S3 in the electronic edition of $B S S A)$. In the checkerboard test, the synthetic times are computed through the 1D starting velocity model with $\pm 5 \%$ velocity anomalies across three grid nodes. The results are shown in Figure S4 (see the (E) electronic edition of BSSA). Note that in this test, we did not include the Moho interface, but still removed low-velocity anomalies as was done for the real data inversion. Some smearing is still seen, part of which is likely due to the interpolation of velocities when obtaining the starting velocities for subregion models.

\section{Final $P$-Wave Velocity Model}

Map Views. Figure 6 shows map view slices through the resulting tomographic $P$ velocity model. Pink dots in each figure represent earthquakes relocated within $\pm 1 \mathrm{~km}$ of each layer depth. The white contours enclose the areas where the derivative weight sum (DWS; Thurber and Eberhart-Phillips, 1999) is greater than 300. Derivative weight sum measures the sampling of each node and serves as an approximate measure of resolution (Zhang and Thurber, 2007). Areas with DWS values above 300 correspond to well-resolved areas in the synthetic tests. In the following, we show average velocities at each layer computed for these areas. In order to quantitatively compare our model with previous tomography models, we interpolated the southern and northern California models by Lin et al. (2007) and Thurber et al. (2009) onto our inversion grids and calculated the correlation coefficients at each layer depth. We will refer to these two models as the $\mathrm{SC}$ and $\mathrm{NC}$ models in the following.

Figure 6a,b shows the $P$-wave velocities in the top two layers of our model. The average velocity values are $5.26 \mathrm{~km} / \mathrm{sec}$ at $1 \mathrm{~km}$ and $6.0 \mathrm{~km} / \mathrm{sec}$ at $4 \mathrm{~km}$ depth. The ve- locities in these shallow layers generally correlate with the surface geology. Lower values are observed in basin and valley areas, such as the Great Valley, southern San Joaquin Valley, Ventura basin, Los Angeles basin, and Imperial Valley, whereas relatively higher velocities are present in the mountain ranges, such as the northern Coast Ranges, Transverse Ranges, Peninsular Ranges, and Sierra Nevada. The correlation coefficients for the well-resolved areas of these two layers between our model and the NC model are 0.49 and 0.56, respectively. The relatively low correlations for these two layers are mainly due to the low-velocity anomalies in the Great Valley and fast anomalies in the Sierra Nevada in our model. The lowest velocity anomalies (about $2.9 \mathrm{~km} / \mathrm{sec}$ ) appear in the Great Valley and southern San Joaquin Valley. However, these slow anomalies are at the edge of our wellresolved areas because of the sparse event distribution in this region. Fairly high-velocity anomalies $(\sim 6.0 \mathrm{~km} / \mathrm{sec})$ at $1 \mathrm{~km}$ depth in the Klamath Mountains and Mount Shasta area are observed that are consistent with the results from seismicrefraction and gravity data in this area (Zucca et al., 1986; Fuis et al., 1987), but are not seen in the recent northern California $P$-wave velocity model by Thurber et al. (2009). This highvelocity body extends to $14 \mathrm{~km}$ depth in our model, reaching $\sim 6.5-6.7 \mathrm{~km} / \mathrm{sec}$ at $4 \mathrm{~km}, \sim 6.7-7.1 \mathrm{~km} / \mathrm{sec}$ at $8 \mathrm{~km}$, and $\sim 7-7.1 \mathrm{~km} / \mathrm{sec}$ at $14 \mathrm{~km}$ depth, with relatively little structural variations along the north-south direction. These velocities are consistent with the conclusion by Fuis et al. (1987), who argued that an imbricated stack of oceanic rock layers underlies the Klamath Mountains. Another high-velocity anomaly zone is apparent at 1 and $4 \mathrm{~km}$ depth in the Lake Oroville area. The $\sim 6.8 \mathrm{~km} / \mathrm{sec}$ velocity at $4 \mathrm{~km}$ depth is generally consistent with the observations by Spieth et al. (1981) that the velocity is of the order of $7.0 \mathrm{~km} / \mathrm{sec}$ at a depth of $5 \mathrm{~km}$. This high-velocity anomaly $(\sim 6.9 \mathrm{~km} / \mathrm{sec})$ extends to $8 \mathrm{~km}$ depth in our model. The high velocities at $1 \mathrm{~km}$ depth in the southern Sierra Nevada area, ranging from $5.2 \mathrm{~km} / \mathrm{sec}$ to $5.8 \mathrm{~km} / \mathrm{sec}$, are consistent with the results of Fliedner et al. $(1996,2000)$. The velocities at $4 \mathrm{~km}$ depth are generally higher than those estimated by Thurber et al. (2009) $(\sim 6.0 \mathrm{~km} / \mathrm{sec}$ compared with $\sim 5.3 \mathrm{~km} / \mathrm{sec}$ ); our model is more consistent with the results based on the active seismic refraction experiment by Fliedner et al. (1996, 2000).

In southern California, the correlation coefficients for these two layers between our model and the SC model are 0.65 and 0.56 , respectively. Note that these coefficients are computed over the resolved areas in the model of Lin $e t$ al. (2007), corresponding to the area of $X=-100$ to $200 \mathrm{~km}$ and $Y=-620$ to $-100 \mathrm{~km}$. Near-surface velocities in our model are also relatively high in the western Mojave Desert in our model. The anomalies are slightly higher than previous results (e.g., Hauksson, 2000; Lin et al., 2007). We think this may be due to the inclusion of the active-source data in this area, which were not used before. In the Imperial Valley area, the slowest velocity at $1 \mathrm{~km}$ depth is $3.07 \mathrm{~km} / \mathrm{sec}$ in this study, but about $3.6 \mathrm{~km} / \mathrm{sec}$ at the surface in Lin et al. (2007), who concluded that their model slightly overestimates 
(a)

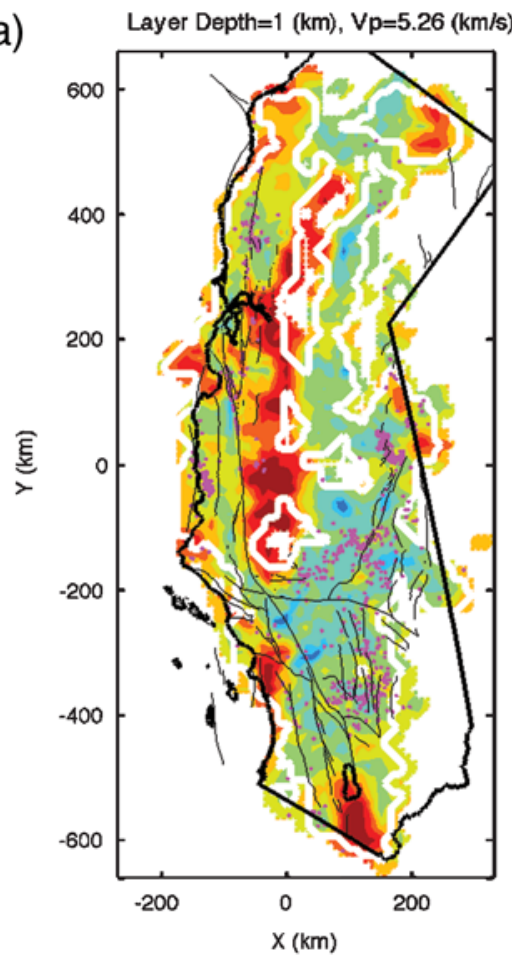

(c)

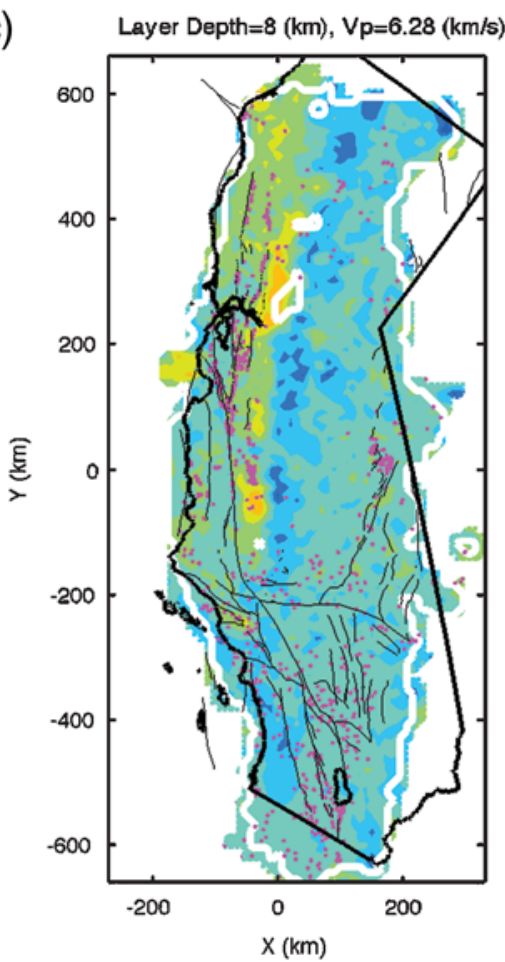

(b)

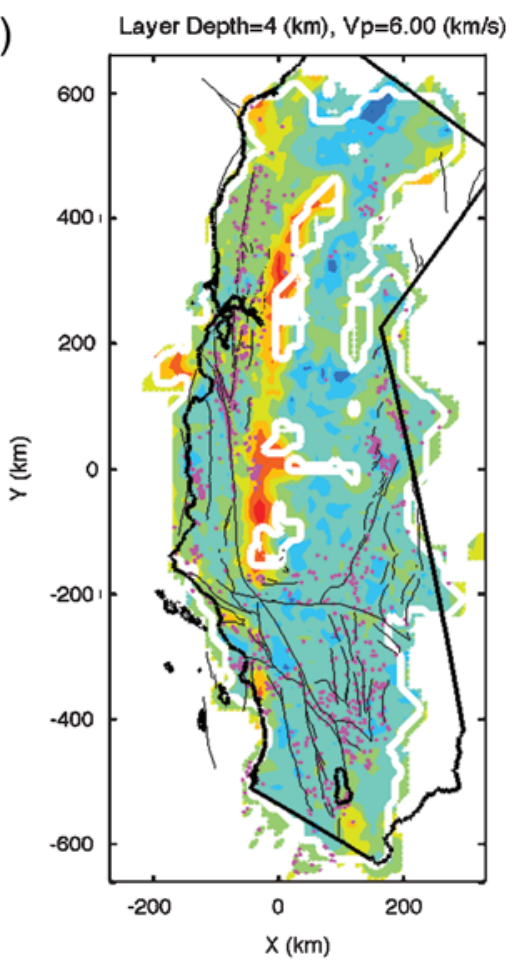

(d)

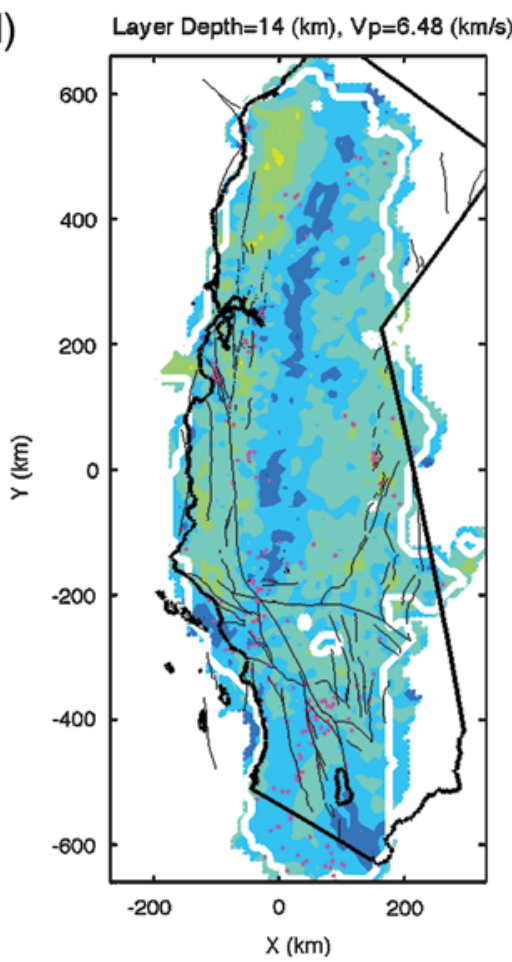

$\begin{array}{lllllllllll}3 & 3.5 & 4 & 4.5 & 5 & 5.5 & 6 & 6.5 & 7 & 7.5 & 8\end{array}$

Figure 6. Map views of the $P$-wave velocity model at different depth slices. The white contours enclose the areas where the derivative weight sum is greater than 300 . The average velocities are computed over these areas. Pink dots represent relocated earthquakes. Black lines denote coast line and lakes, gray lines rivers and surface traces of mapped faults. 
(e)

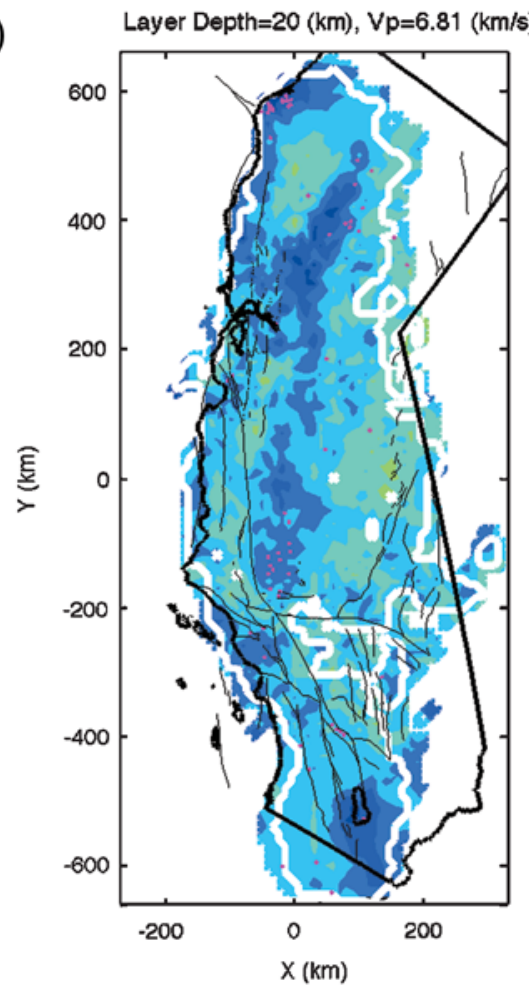

(g)

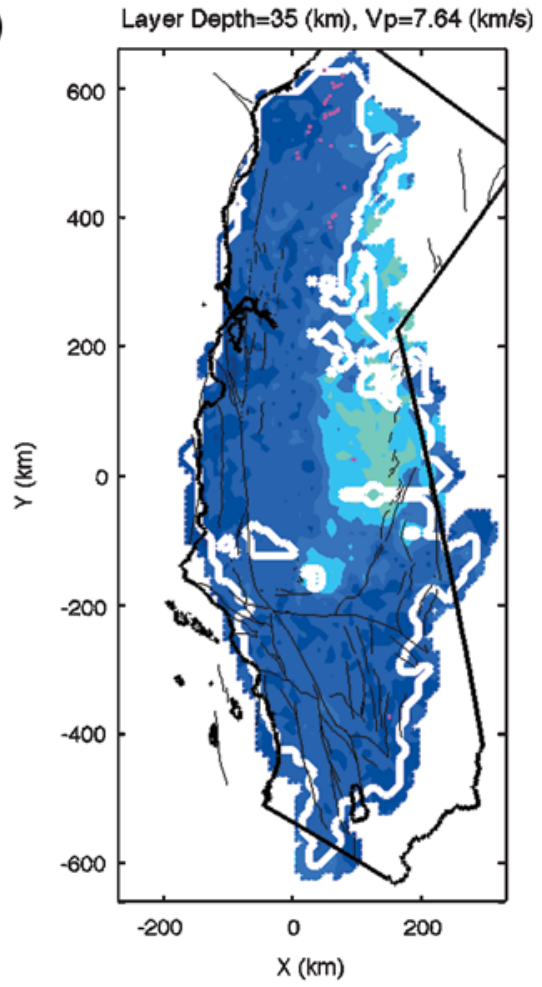

(f)

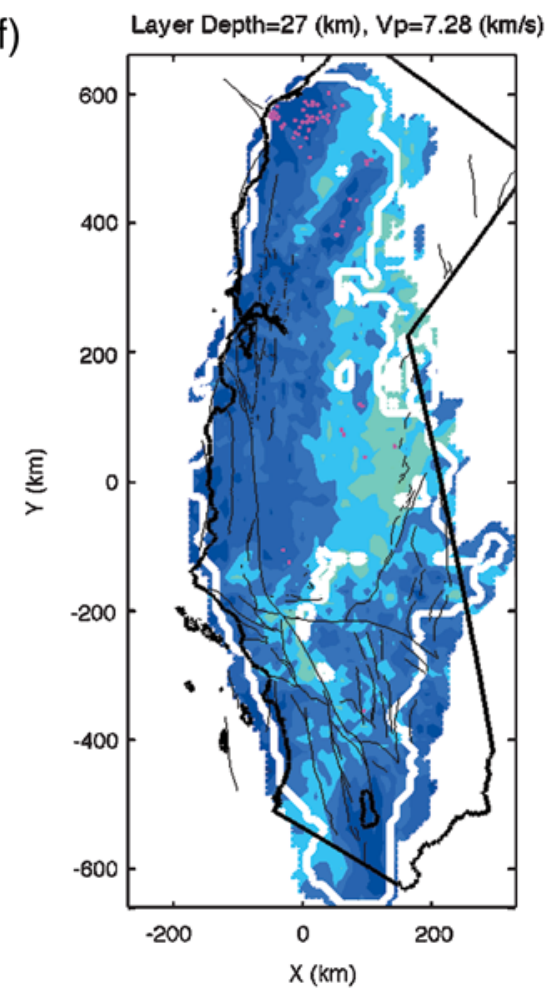

(h)

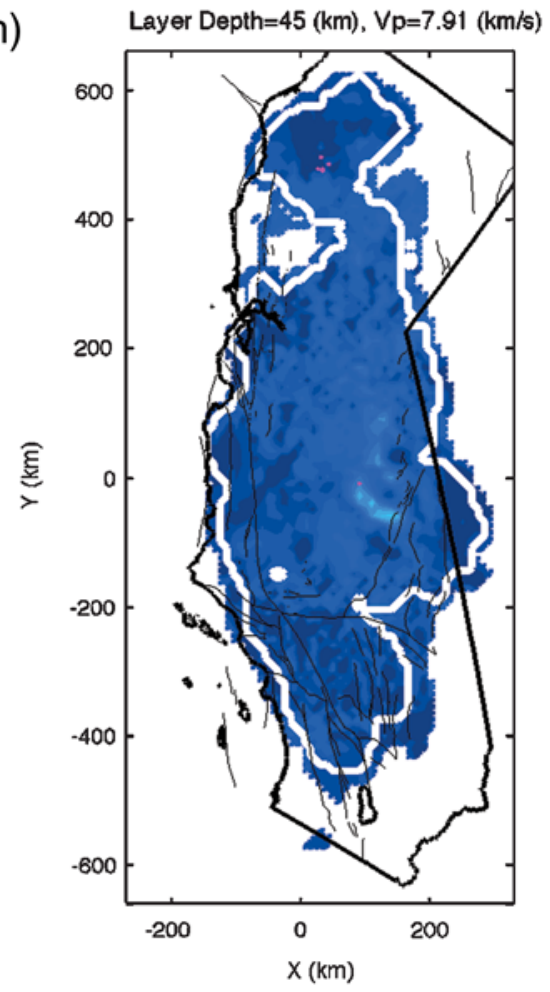

$\begin{array}{lllllllllll}3 & 3.5 & 4 & 4.5 & 5 & 5.5 & 6 & 6.5 & 7 & 7.5 & 8\end{array}$

Figure 6. Continued. 
the near-surface velocity compared with seismic refraction results (Fuis et al., 1984). The reduction of this overestimation indicates that our model has better resolution for near-surface structure. The southern San Joaquin Valley is better resolved in this new model, which is at the northern boundary of the study area in Lin et al. (2007).

Figure 6c,d shows map views for 8 and $14 \mathrm{~km}$ depths, with average velocity values of $6.26 \mathrm{~km} / \mathrm{sec}$ and $6.46 \mathrm{~km} / \mathrm{sec}$, respectively. These layers are the two bestresolved layers in our model because of the abundant seismicity at these depths, and the results are generally quite compatible with previous tomographic results. At $8 \mathrm{~km}$ depth, a strong velocity contrast is apparent between the Great Valley and the Sierra Nevada. At $14 \mathrm{~km}$ depth, some of the features we imaged for the shallow layers are reversed, that is, the basin and valley areas show relatively high-velocity anomalies and lower values are present under the mountain ranges. The reversal of the velocity anomalies associated with most of the major basins is also observed in previous southern and northern California tomography studies (Lin et al., 2007; Thurber et al., 2009). The correlation coefficients for these two layers between our model and the $\mathrm{NC}$ model are 0.61 and 0.47 , and 0.35 and 0.49 with the $\mathrm{SC}$ model, respectively. The relatively poor correlation with the NC model is mainly due to the slower velocities ( $2 \%)$ in the northern Coast Ranges than what is observed in the Thurber et al. (2009) model. The correlation coefficients with the SC model are reduced compared with the shallower layers. For these two layers, our model is generally faster than the Lin et al. (2007) model by about $5 \%$ in the basin areas, such as the Ventura basin, Los Angeles basin, and Imperial Valley.

Map views for the 20 and $27 \mathrm{~km}$ depth layers are shown in Figure $6 \mathrm{e}, \mathrm{f}$, with average velocity values of $6.81 \mathrm{~km} / \mathrm{sec}$ and $7.28 \mathrm{~km} / \mathrm{sec}$, respectively. The correlation coefficients for these two layers between our model and the NC model are 0.65 and 0.72 , respectively. The resolution of the southern California model by Lin et al. (2007) is poor below $17 \mathrm{~km}$ depth, so we focus on the comparison in northern California. At $20 \mathrm{~km}$ depth, the model is consistent with the results of Thurber et al. (2009), but is slightly slower in the center of the Great Valley. At $27 \mathrm{~km}$ depth, the Sierra Nevada area shows about $6.0 \mathrm{~km} / \mathrm{sec}$ low-velocity anomalies, but in the same area, the velocity in Thurber et al. (2009) is about $6.5 \mathrm{~km} / \mathrm{sec}$. Our model extends to $45 \mathrm{~km}$ depth. Figure $6 \mathrm{~g}$,h shows the map views of the last two layers at $35 \mathrm{~km}$ and $45 \mathrm{~km}$ depths. Although the model is not resolved nearly as well as the shallower layers, we are able to see the low-velocity anomalies in the Sierra Nevada region; the correlation coefficients for these two layers between our model and the NC model are 0.70 and 0.46 , respectively.

Cross Sections. We present three cross sections to illuminate the large-scale features of the model. One is parallel to the San Andreas fault (SAF; $X=0 \mathrm{~km}$ in the Cartesian coordinate system), and the other two are perpendicular to the SAF $(Y=210 \mathrm{~km}$ and $Y=-30)$. A complete set of cross sections is provided in the (E) electronic edition of BSSA. In Figure 7 we show the velocity cross sections through the resulting model along the three profiles whose locations are shown in Figure 1.

The $X=0 \mathrm{~km}$ section in Figure 7a starts in the northern Coast Ranges where intermediate velocities $\left(V_{P}<\right.$ $6.2 \mathrm{~km} / \mathrm{sec}$ ) extend into the lower crust. At depths greater than $20 \mathrm{~km}$, the seismicity and high velocities of the subducting Gorda Plate are visible. From $Y \sim 350$ to $-210 \mathrm{~km}$, the low near-surface velocities of the Great Valley and southern San Joaquin Valley sediments and sedimentary rocks are evident, extending to depths of $\sim 10 \mathrm{~km}$ in the northwest and to $\sim 4 \mathrm{~km}$ in the southeast. High-velocity rocks $\left(V_{P} \sim\right.$ $6.5 \mathrm{~km} / \mathrm{sec}$ ) of the underlying Great Valley ophiolite body are present throughout this part of the section. The section crosses the Garlock fault $(Y \sim-210 \mathrm{~km})$ and the SAF $(Y \sim-255 \mathrm{~km})$, where upper and midcrustal velocities are relatively low $\left(V_{P}<6.3 \mathrm{~km} / \mathrm{sec}\right)$, and then cuts through the San Gabriel Mountains (SGM) and Peninsular Ranges where the upper crust velocities are relatively high $\left(V_{P}>\right.$ $6.2 \mathrm{~km} / \mathrm{sec}$ ) at shallow depths. Beneath the SAF and SGM, a strong low-velocity zone is apparent, as identified in
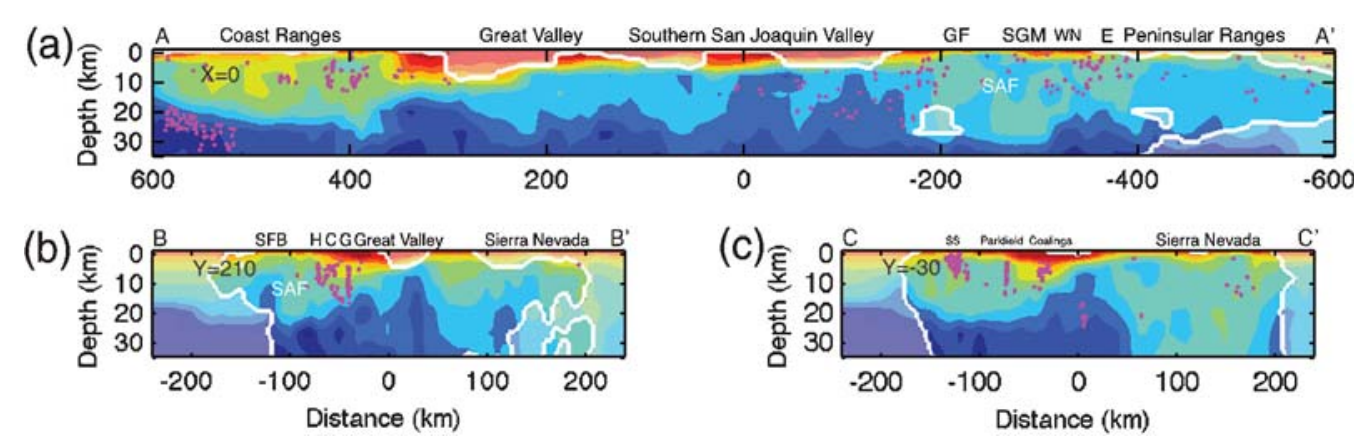

Figure 7. Cross sections of the absolute $P$-wave velocity along the three profiles shown in Figure 1 . Again, the pink dots represent relocated earthquakes and the white contours enclose the area where the derivative weight sum is less than 300 . Color scale is the same as in Figure 6. Abbreviations: C, Calaveras fault; E, Elsinore fault; GF, Garlock fault; G, Greenville fault; H, Hayward fault; SAF, San Andreas fault; SFB, San Francisco Bay; SGM, San Gabriel Mountains; SS, San Simeon; WN, Whittier Narrows. 
previous studies in this area, which has been interpreted to indicate fluids (e.g., Ryberg and Fuis, 1998; Fuis et al., 2000).

The section in Figure $7 \mathrm{~b}$ cuts across the seismically quiet southern San Francisco (SF) Peninsula and SF Bay $(X=-120$ to $-90 \mathrm{~km})$ and then reaches the seismically active Hayward, Calaveras, and Greenville faults beneath the East Bay $(X=-70$ to $-30 \mathrm{~km})$. The section then enters the Great Valley, where the high-velocity basement, thought to be ophiolite (e.g., Godfrey et al., 1997), shallows to the northeast $(X=-30$ to $+50 \mathrm{~km})$. After that, the section enters the Sierra Nevada where a thicker crust with a velocity of $\sim 6.2 \mathrm{~km} / \mathrm{sec}$ extends to $32 \mathrm{~km}$ depth. The section in Figure 7c passes through the seismic activity of San Simeon $(X=-120 \mathrm{~km})$, Parkfield $(X=-75 \mathrm{~km})$, and Coalinga $(X=-30 \mathrm{~km})$. Even with the $10 \mathrm{~km}$ model gridding, the velocity contrast across the San Andreas at Parkfield is evident (southwest side faster, e.g., Thurber et al., 2006). In this section as well, the high-velocity Great Valley ophiolite body is evident with a predominantly southwestern dip of its upper surface, consistent with potential field data (Jachens et al., 1995). At $X \sim 50 \mathrm{~km}$, we see a transition to the slower, thicker crust of the Sierra Nevada.

\section{$S$-Wave Velocity Model}

Although $S$-wave velocity models in northern California are available from ambient noise and surface wave data (e.g., Yang et al., 2008), there is no 3D model based on regional network data. In this study, we use the $S$ first-arrival times from the SCSN and USArray to solve for a $V_{S}$ model. Note that these data are different from those used for the $V_{P}$ model. Figure 8a shows the 1020 SCSN and 1292 USArray events with at least $4 P$ and $4 S$ picks. Due to the sparse distribution of the data, we use the velocity inversion nodes of the 3D coarse $V_{P}$ model (i.e., 30 by $30 \mathrm{~km}$ horizontal node spacing). The starting $S$ velocities are derived from our resolved $V_{P}$ model and a constant $V_{P} / V_{S}$ of 1.73. The resolution estimated by the DWS values is quite poor. In order to test the robustness of the $S$ model, we also start with the $S$ velocity values from the ambient noise and teleseismic multiple-plane-wave tomography results by Yang et al. (2008). The well-resolved part agrees with the results starting with the constant $V_{P} / V_{S}$, indicating that the model is relatively robust. Figure $8 \mathrm{~b}$ shows the map view of our resolved $V_{S}$ model at $8 \mathrm{~km}$ depth. The white contours enclose the area where the derivative weight sum is greater than 100 . We also compared our $V_{P}$ and $V_{S}$ models to the empirical $V_{P}-V_{S}$ (a)

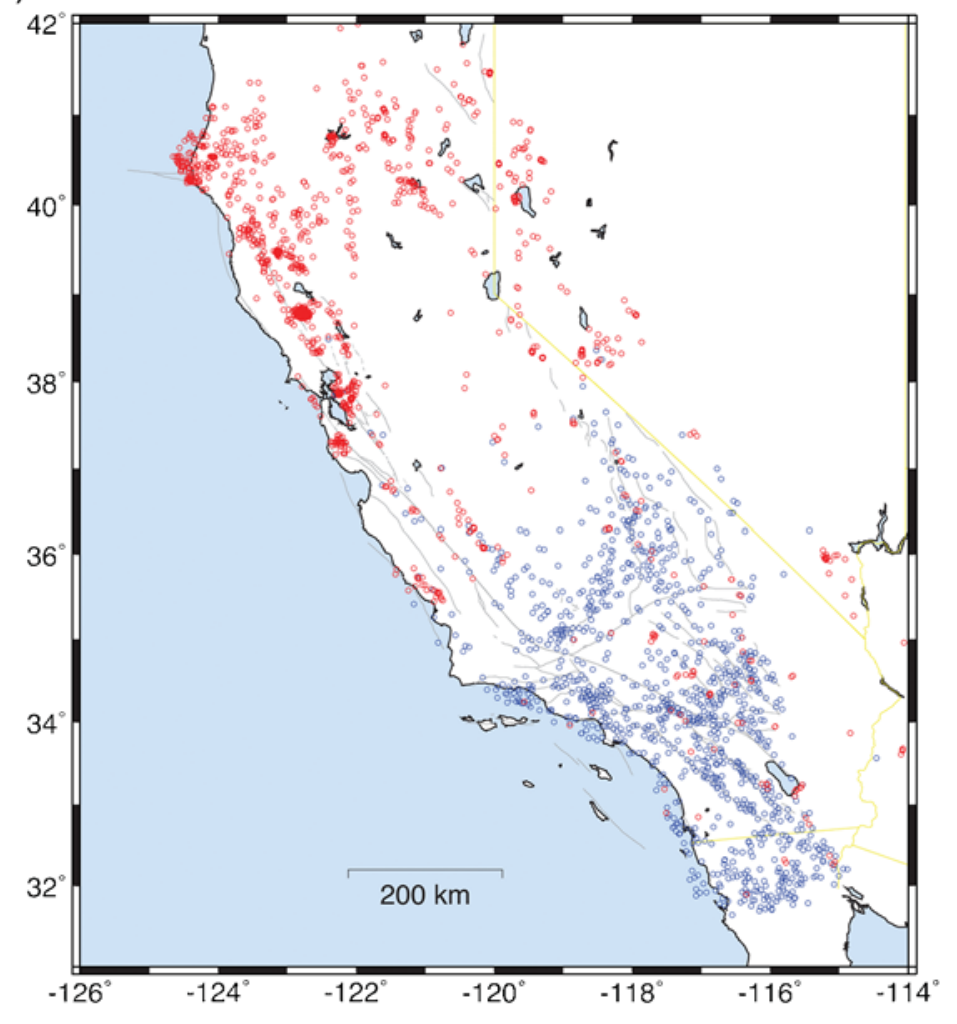

(b)

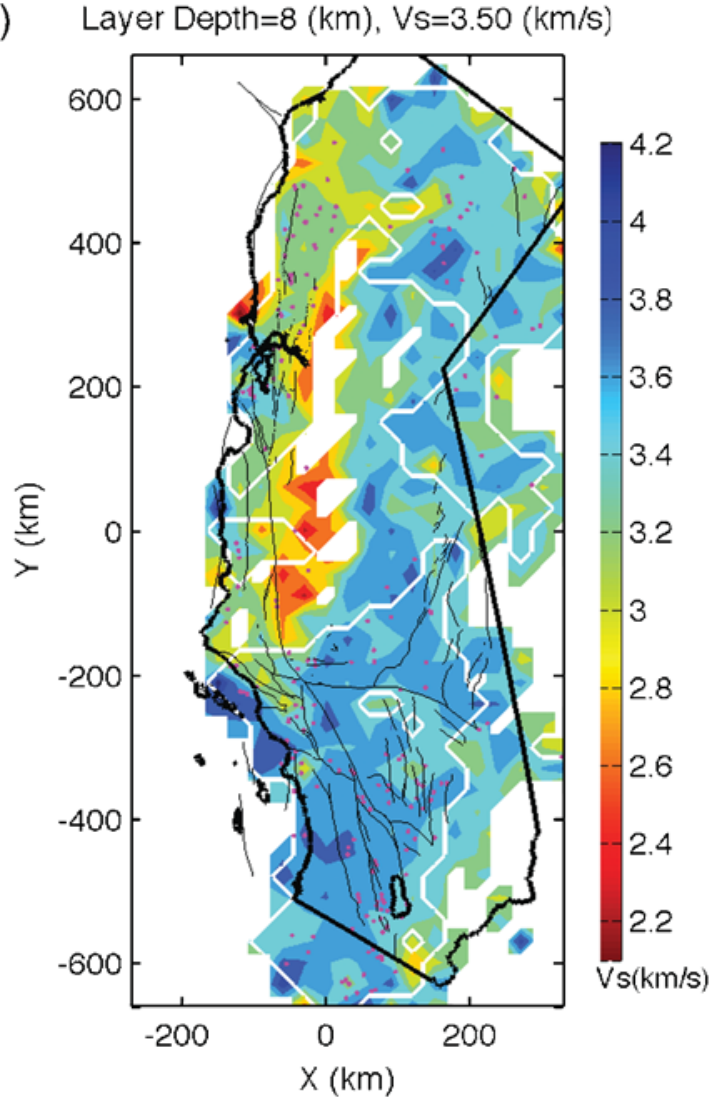

Figure 8. (a) Event distribution for $V_{S}$ model. The red and blue circles represent the events from the USArray and SCSN, respectively. (b) Map view of our resolved $V_{S}$ model at $8 \mathrm{~km}$ depth. Areas where the derivative weight sum is greater than 100 are shown. The average velocity is computed over these areas. The pink dots represent relocated earthquakes. 
relation of Brocher (2005). This relation is derived from a diverse dataset, including wireline borehole logs, vertical seismic profiles, laboratory measurements, and seismic tomography models, and can be used to infer $V_{S}$ for the entire Earth's crust from $V_{P}$. Using the layer-average $P$ velocities as inputs, we obtained the corresponding empirical $S$ velocities. Our comparison indicates that the tomographybased $V_{S}$ results are faster than predicted by the empirical relation at 1 and $35 \mathrm{~km}$ depth, and lower than expected at $8 \mathrm{~km}$ depth. Due to the poor resolution of this model, we do not attempt to solve for Poisson's ratio and other parameters that depend on $V_{P} / V_{S}$ values. A complete set of map views and cross sections of our $S$-wave model is provided in the (E) electronic edition of BSSA).

\section{Discussion}

Our model is the first 3D seismic velocity model for the entire state of California based on local and regional arrivaltime data. It has improved areal coverage compared with the previous northern and southern California models, and extends to greater depth due to the inclusion of substantial data at large epicentral distances. The combination of northern, southern, and central California data sets results in betterresolved velocity structure at the study boundaries of previous tomographic models, such as the San Joaquin Valley and southern Sierra Nevada. Because of the $10 \mathrm{~km}$ horizontal grid spacing in our model inversion, which is larger than the distance cutoff of most waveform cross-correlation calculations $(\leq 5 \mathrm{~km})$, we did not apply any differential times from cross-correlation in this study. There may be some finer-scale structures that are not resolved due to the data and grid spacing used in our model. We compared our model with some results based on refraction and/or reflection data. Our model generally agrees with most of the studies, such as in the Diablo and Gabilan Ranges (Steppe and Robert, 1978; Walter and Mooney, 1982), the Coyote Lake (Mooney and Luetgert, 1982), the Long Valley (Luetgert and Mooney, 1985), the San Francisco Bay area (Holbrook et al., 1996), the southern Sierra (Fliedner et al., 1996), and the Mojave Desert (Fuis, Ryberg, et al., 2001); but slightly overestimates near-surface velocity values in some basins and valleys, such as in the Imperial Valley (McMechan and Mooney, 1980; Fuis et al., 1984), the Great Valley (Colburn and Mooney, 1986), the Livermore area (Meltzer et al., 1987), and the greater Los Angeles basin (Fuis, Ryberg, et al., 2001b).

The differences between this statewide velocity model and previous regional-scale models are due to several factors, such as data sets, grid spacing (cell size), tomographic algorithms, and inversion parameters (e.g., damping, smoothing, and residual weighting). The model is very similar to the recent northern California model by Thurber et al. (2009) for the middle to lower crust because the two studies use the same type of data sets (both absolute and differential times) and inversion algorithm (tomoFDD), whereas the southern California model by Lin et al. (2007) is derived by applying the SIMULPS algorithm (Thurber, 1983, 1993; Eberhart-Phillips, 1990; Evans et al., 1994) to absolute arrival times for composite events. We also calculated the correlation coefficients, which are $0.67,0.56,0.36,0.54$, and 0.69 for the top five layers, between our model and the SCEC unified velocity model (Version 4, Magistrale et al., 2000). Note that the SCEC model is based on geotechnical borehole seismic velocity data and the regional tomographic model of Hauksson (2000), which is also obtained by applying the SIMULPS algorithm. The slightly better correlation at $1 \mathrm{~km}$ depth is due to the low-velocity anomalies in the basin areas. Our new model is generally consistent with these previous results. The improved resolution of our model in nearsurface layers over the previous California tomographic models is mainly due to the large amount of active-source data in this study.

The goal of this study is not to replace the previous tomographic models in California that have more detail than can be resolved by our data and grid spacing, but to image the entire state of California at a regional scale, to reveal some features that are difficult to resolve in local studies, and to provide the geophysical community with a velocity model that should be useful for regional-scale studies, such as regional waveform modeling. The model is available in the (E) electronic edition of BSSA.

\section{Conclusions}

We have developed statewide body-wave tomography models $(P$ and $S$ ) for California using absolute and differential arrival times from earthquakes, controlled sources, and quarry blasts. By merging the data sets from networks in northern, southern, and coastal central California and USArray, we have achieved relatively complete coverage of the entire state for $V_{P}$. By including a large amount of active-source data in this study, we obtained improved resolution in near-surface layers over the previous California tomographic models, especially in the largest sedimentary basins, such as the Great Valley, the Imperial Valley, and the Los Angeles basin. At $8 \mathrm{~km}$ depth, there is a clear north to south increase in the average velocity of the Coast Range Mountains extending from the Mendocino Triple Junction to the border with Mexico. At 14 and $20 \mathrm{~km}$ depths, the basin and valley areas show relatively high-velocity anomalies, with lower velocities present under the mountain ranges. The Great Valley ophiolite body and the subducting Gorda Plate are evident from the cross sections. Low-velocity anomalies in the Sierra Nevada exist from midcrustal to greater depths; the slow velocity root over this area is the largest anomaly at $35 \mathrm{~km}$ depth. Our model provides a reasonable fit to the data and relocates explosions, treated as earthquakes, with an absolute accuracy of better than a kilometer. Thus, it should be useful for producing a statewide earthquake location catalog based on a single velocity model. 


\section{Data and Resources}

Active-source data used in this study were collected from published studies listed in the references. Catalog picks were obtained from the USArray, the Northern California Earthquake Data Center (NCEDC), and the Southern California Earthquake Data Center (SCEDC) and originate principally from the Northern California Seismic Network (NCSN) and Southern California Seismic Network (SCSN). Some figures were made using the public domain Generic Mapping Tools software (Wessel and Smith, 1991).

\section{Acknowledgments}

We thank the U.S. Geological Survey (USGS) and Caltech staff for maintaining the NCSN and SCSN, and the IRIS Data Management Center for making USArray data available. R. Catchings,C. Evangelidis, A. Frankel, G. Fuis, S. Hartzell, W. Kohler, A. Lindh, J. Murphy, D. O'Connell, and T. Parsons contributed first-arrival times and receiver and source locations for active-source experiments in the study area. We thank W.-X. Du for his effort to assemble the northern California active-source data set into a consistent form and Y. Yang for providing his ambient noise tomography model. This work is supported by the National Earthquake Hazards Reduction program, under USGS awards 07HQGR0038, 07HQGR0045, 07HQGR0047, 07HQGR0050, 08HQGR0032, 08HQGR0039, 08HQGR0042 and 08HQGR0045, and the National Mapping Programs of the USGS. The views and conclusions contained in this document are those of the authors and should not be interpreted as necessarily representing the official policies, either expressed or implied, of the U.S. government.

\section{References}

Begnaud, M. L., K. C. McNally, D. S. Stakes, and V. A. Gallardo (2000). A crustal velocity model for locating earthquakes in Monterey Bay, California, Bull. Seismol. Soc. Am. 90, 1391-1408, doi 10.1785/ 0120000016.

Bleibinhaus, F., J. A. Hole, T. Ryberg, and G. S. Fuis (2007). Structure of the California Coast Ranges and San Andreas Fault at SAFOD from seismic waveform inversion and reflection imaging, J. Geophys. Res. 112, B06315, doi 10.1029/2006JB004611.

Boyd, O. S., C. H. Jones, and A. F. Sheehan (2004). Foundering lithosphere imaged beneath the southern Sierra Nevada, California, USA, Science 305, 660-662.

Brocher, T. M. (2005). Empirical relations between elastic wavespeeds and density in the Earth's crust, Bull. Seismol. Soc. Am. 95, 2081-2092.

Brocher, T. M., and D. C. Pope (1994). Onshore-offshore wide-angle seismic recordings of the San Francisco Bay Area Seismic Imaging eXperiment (BASIX); data from the Northern California Seismic Network, U.S. Geol. Surv. Open-File Rept. 94-156.

Brocher, T. M., P. E. Hart, and S. Carle (1989). Feasibility study of the seismic reflection method in Amargosa Desert, Nye County, Nevada, U.S. Geol. Surv. Open-File Rept. 89-133, 150 pp.

Brocher, T. M., M. J. Moses, and S. D. Lewis (1992). Wide-angle seismic recordings obtained during seismic reflection profiling by the S. P. Lee offshore the Loma Prieta epicenter, U.S. Geol. Surv. Open-File Rept. 92-245, 63 pp.

Catchings, R. D., M. R. Goldman, C. E. Steedman, and G. Gandhok (2004). Velocity models, first-arrival travel times, and geometries of 1991 and 1993 USGS land-based controlled-source seismic investigations in the San Francisco Bay Area, California: In-line Shots, U.S. Geol. Surv. Open-File Rept., 2004-1423, 32 pp.

Colburn, R. H., and W. D. Mooney (1986). Two-dimensional velocity structure along the synclinal axis of the Great Valley, California, Bull. Seismol. Soc. Am. 76, 1305-1322.
Colburn, R. H., and A. W. Walter (1984). Data report for two seismicrefraction profiles crossing the epicentral region of the 1983 Coalinga, California earthquakes, U.S. Geol. Surv. Open-File Rept. 84-643, $58 \mathrm{pp}$.

Eberhart-Phillips, D. (1986). Three-dimensional velocity structure in the northern California Coast Ranges from inversion of local earthquake arrival times, Bull. Seismol. Soc. Am. 76, 1025-1052.

Eberhart-Phillips, D. (1990). Three-dimensional $P$ and $S$ velocity structure in the Coalinga region, California, J. Geophys. Res. 95, 15,343-15,363.

Eberhart-Phillips, D. (1993). Local earthquake tomography: earthquake source regions, in Seismic Tomography: Theory and Practice, H. M. Iyer and K. Hirahara (Editors), Chapman and Hall, London, 613-643.

Eberhart-Phillips, D., and A. J. Michael (1993). Three-dimensional velocity structure, seismicity, and fault structure in the Parkfield region, central California, J. Geophys. Res. 98, 15737-15758.

Eberhart-Phillips, D., and A. J. Michael (1998). Seismotectonics of the Loma Prieta, California, region determined from three-dimensional $V_{P}, V_{P} / V_{S}$, and seismicity, J. Geophys. Res. 103, 21,099-21,120.

Evans, J. R., D. Eberhart-Phillips, and C. H. Thurber (1994). User's manual for SIMULPS12 for imaging $V_{P}$ and $V_{P} / V_{S}$ : A derivative of the "Thurber" tomographic inversion SIMUL3 for local earthquakes and explosions, U.S. Geol. Surv. Open-File Rept. 94-431.

Flanagan, M. P., S. C. Myers, and K. D. Koper (2007). Regional travel-time uncertainty and seismic location improvement using a threedimensional a priori velocity model, Bull. Seismol. Soc. Am. 97, 804-825.

Fliedner, M. M., S. L. Klemperer, and N. I. Christensen (2000). Threedimensional seismic model of the Sierra Nevada arc, California, and its implications for crustal and upper mantle composition, J. Geophys. Res. 105, 10899-10922.

Fliedner, M. M., S. Ruppert, and the Southern Sierra Nevada Continental Dynamics Working Group (1996). Three-dimensional crustal structure of the southern Sierra Nevada from seismic fan profiles and gravity modeling, Geology 24, 367-370.

Foxall, W., A. Michelini, and T. V. McEvilly (1993). Earthquake travel time tomography of the southern Santa Cruz Mountains: Control of fault rupture by lithological heterogeneity of the San Andreas Fault zone, J. Geophys. Res. 98, 17,691-17,710.

Fuis, G., and W. D. Mooney (1990). Lithospheric structure and tectonics from seismic-refraction and other data, The San Andreas Fault System, California: U.S. Geol. Surv. Prof. Paper 1515, 207-236.

Fuis, G. S., W. D. Mooney, J. H. Healy, G. A. McMechan, and W. J. Lutter (1984). A seismic refraction survey of the Imperial Valley region, California, J. Geophys. Res. 89, 1165-1190.

Fuis, G. S., J. M. Murphy, D. A. Okaya, R. W. Clayton, P. M. Davis, K. Thygesen, S. A. Baher, T. Ryberg, M. L. Benthien, G. Simila, J. T. Perron, A. K. Yong, L. Reusser, W. J. Lutter, G. Kaip, M. D. Fort, I. Asudeh, R. Sell, J. R. Vanschaack, E. E. Criley, R. Kaderabek, W. M. Kohler, and N. H. Magnuski (2001). Report for borehole explosion data acquired in the 1999 Los Angeles region seismic experiment (LARSE II), southern California. I. Description of the survey, U.S. Geol. Surv. Open-File Rept. 01-408, 82 pp.

Fuis, G. S., T. Ryberg, N. J. Godfrey, D. A. Okaya, and J. M. Murphy (2001b). Crustal structure and tectonics from the Los Angeles basin to the Mojave Desert, southern California, Geology 29, 15-18.

Fuis, G. S., T. Ryberg, N. J. Godfrey, D. A. Okaya, W. J. Lutter, J. M. Murphy, and V. E. Langenheim (2000). Crustal structure and tectonics of the San Andreas Fault in the Central Transverse Ranges/Mojave Desert Area, $3 r d$ Conference on Tectonic Problems of the San Andreas Fault System.

Fuis, G. S., J. J. Zucca, W. D. Mooney, and B. Milkereit (1987). A geologic interpretation of seismic-refraction results in northeastern California, Geol. Soc. Am. Bull. 98, 53-65.

Godfrey, N. J., B. C. Beaudoin, and S. L. Klemperer (1997). Ophiolitic basement to the Great Valley forearc basin, California, from seismic and gravity data: Implications for crustal growth at the North American continental margin, Geol. Soc. Am. Bull. 109, 1536-1562. 
Hardebeck, J. L., A. J. Michael, and T. M. Brocher (2007). Seismic velocity structure and seismotectonics of the eastern San Francisco Bay region, California, Bull. Seismol. Soc. Am. 97, 826-842.

Harris, R., A. W. Walter, and G. S. Fuis (1988). Data report for the 19801981 seismic-refraction profiles in the western Mojave Desert, California, U.S. Geol. Surv. Open-File Rept. 88-580, 65 pp.

Hauksson, E. (2000). Crustal structure and seismicity distribution adjacent to the Pacific and North America plate boundary in southern California, J. Geophys. Res. 105, 13,875-13,903.

Hauksson, E., and J. S. Haase (1997). Three-dimensional $V_{P}$ and $V_{P} / V_{S}$ velocity models of the Los Angeles basin and central Transverse Ranges, California, J. Geophys. Res. 102, 5423-5453.

Hauksson, E., and J. Unruh (2007). Regional tectonics of the Coso geothermal area along the intracontinental plate boundary in central eastern California: Three-dimensional $V_{P}$ and $V_{P} / V_{S}$ models, spatialtemporal seismicity patterns, and seismogenic deformation, J. Geophys. Res. 112, B06309, doi10.1029/2006JB004721.

Hellweg, M., D. Given, E. Hauksson, D. Neuhauser, D. Oppenheimer, and A. Shakal (2007). The California Integrated Seismic Network, Eos Trans. AGU 88, Jt. Assem. Suppl., Abstract S33C-07.

Henstock, T. J., A. Levander, and J. A. Hole (1997). Deformation in the lower crust of the San Andreas Fault System in northern California, Science 278, 650-653.

Holbrook, W. S., T. M. Brocher, U. S. ten Brink, and J. A. Hole (1996). Crustal structure of a transform plate boundary: San Francisco Bay and the central California continental margin, J. Geophys. Res. 101, 22,311-22,334.

Hole, J. A., T. Ryberg, G. S. Fuis, F. Bleibinhaus, and A. K. Sharma (2006). Structure of the San Andreas Fault zone at SAFOD from a seismic refraction survey, Geophys. Res. Lett. 33, doi 10.1029/ 2005GL025194

Huang, J.-1., and D. Zhao (2003). $P$-wave tomography of crust and upper mantle under southern California: Influence of topography of Moho discontinuity, Acta Seismologica Sinica 16, 577-587.

Hwang, L. J., and W. D. Mooney (1986). Velocity and $Q$ structure of the Great Valley, California, based on synthetic seismogram modeling of seismic refraction data, Bull. Seismol. Soc. Am. 76, 1053-1067.

Jachens, R. C., A. Griscom, and C. W. Roberts (1995). Regional extent of Great Valley basement west of the Great Valley, California: Implications for extensive tectonic wedging in the California Coast Ranges, J. Geophys. Res. 100, 12,769-12,790.

Kohler, W. M., and R. D. Catchings (1994). Data report for the 1993 seismic refraction experiment in the San Francisco Bay Area, California, U.S. Geol. Surv. Open-File Rept. 94-241, 71 pp.

Kohler, W. M., and G. S. Fuis (1988). Data report for the 1979 seismicrefraction experiment in the Imperial Valley region, California, U.S. Geol. Surv. Open-File Rept. 88-255, 96 pp.

Kohler, W. M., G. S. Fuis, and P. A. Berge (1987). Data report for the 19781985 seismic-refraction surveys in northeastern California, U.S. Geol. Surv. Open-File Rept. 87-625, 99 pp.

Lin, G., P. M. Shearer, E. Hauksson, and C. H. Thurber (2007). A threedimensional crustal seismic velocity model for southern California from a composite event method, J. Geophys. Res. 112, doi 10.1029/2007JB004977.

Luetgert, J. H., and W. D. Mooney (1985). Crustal refraction profile of the Long Valley caldera, California, from the January 1983 Mammoth Lakes earthquake swarm, Bull. Seismol. Soc. Am. 75, 211-221.

Lutter, W. J., G. S. Fuis, T. Ryberg, D. A. Okaya, R. W. Clayton, P. M. Davis, C. Prodehl, J. M. Murphy, V. E. Langenheim, M. L. Benthien, N. J. Godfrey, N. I. Christensen, K. Thygesen, C. H. Thurber, G. Simila, and G. R. Keller (2004). Upper crustal structure from the Santa Monica Mountains to the Sierra Nevada, Southern Californnia: Tomographic results from the Los Angeles regional seismic experiment, phase II (LARSE II), Bull. Seismol. Soc. Am. 94, 619-632.

Lutter, W. J., G. S. Fuis, C. H. Thurber, and J. Murphy (1999). Tomographic images of the upper crust from the Los Angeles basin to the Mojave
Desert, California: Results from the Los Angeles Region Seismic Experiment, J. Geophys. Res. 104, 25,543-25,565.

Magistrale, H., S. Day, R. W. Clayton, and R. Graves (2000). The SCEC southern California reference three-dimensional seismic velocity model version 2, Bull. Seismol. Soc. Am. 90, S65-S76.

Magistrale, H., K. McLaughlin, and S. Day (1996). A geology-based 3D velocity model of the Los Angeles basin sediments, Bull. Seismol. Soc. Am. 86, 1161-1166.

Manaker, D. M., A. J. Michael, and R. Burgmann (2005). Subsurface structure and kinematics of the Calaveras-Hayward Fault stepover from three-dimensional $V_{P}$ and seismicity, San Francisco Bay region, California, Bull. Seismol. Soc. Am. 95, 446-470.

McMechan, G. A., and W. D. Mooney (1980). Asymptotic ray theory and synthetic seismograms for laterally varying structures: Theory and application to the Imperial Valley, California, Bull. Seismol. Soc. Am. 70, 2021-2035.

Meador, P. J., D. P. Hill, and J. H. Luetgert (1985). Data report for the JulyAugust 1983 seismic-refraction experiment in the Mono Craters-Long Valley region, California, U.S. Geol. Surv. Open-File Rept. 85-708, $70 \mathrm{pp}$.

Meltzer, A. S., A. R. Levander, and W. D. Mooney (1987). Upper crustal structure, Livermore Valley and vicinity, California coast ranges, Bull. Seismol. Soc. Am. 77, 1655-1673.

Mooney, W. D., and R. H. Colburn (1985). A seismic-refraction profile across the San Andreas, Sargent, and Calaveras faults, west-central California, Bull. Seismol. Soc. Am. 75, 175-191.

Mooney, W. D., and J. H. Luetgert (1982). A seismic refraction study of the Santa Clara Valley and southern Santa Cruz Mountains, west-central California, Bull. Seismol. Soc. Am. 72, 901-909.

Mooney, W. D., and C. S. Weaver (1989). Regional crustal structure and tectonics of the pacific coastal states; California, Oregon and Washington, in Geophysical Framework of the Continental United States, I. C. Pakiser and W. D. Mooney (Editors), Geol. Soc. Am. Mem., 172, 129-161.

Murphy, J. M. (1989). Data report for the Great Valley, California, axial seismic refraction profiles, U.S. Geol. Surv. Open-File Rept. 89494, 36 pp.

Murphy, J. M., and A. W. Walter (1984). Data report for a seismic-refraction investigation: Morro Bay to the Sierra Nevada, California, U.S. Geol. Surv. Open-File Rept. 84-642, 37 pp.

Murphy, J. M., R. D. Catchings, W. M. Kohler, G. S. Fuis, and D. EberhartPhillips (1992). Data report for 1991 active-source seismic profiles in the San Francisco Bay area, U.S. Geol. Surv. Open-File Rept. 92-570, $45 \mathrm{pp}$.

Murphy, J. M., G. S. Fuis, T. Ryberg, D. A. Okaya, E. E. Criley, M. L. Benthien, M. Alvarez, I. Asudeh, W. M. Kohler, G. N. Glassmoyer, M. C. Robertson, and J. Bhowmik (1996). Report for explosion data acquired in the 1994 Los Angeles Region Seismic Experiment (LARSE 94), Los Angeles, California, U.S. Geol. Surv. Open-File Rept. 96-536, 120 pp.

Ryberg, T., and G. S. Fuis (1998). The San Gabriel Mountains bright reflective zone: Possible evidence of young mid-crustal thrust faulting in southern California, Tectonophysics 286, 31-46.

Sharpless, S. W., and A. W. Walter (1988). Data report for the 1986 San Luis Obispo, California, seismic refraction survey, U.S. Geol. Surv. Open-File Rept. 88-35, 48 pp.

Spieth, M. A., D. P. Hill, and R. J. Geller (1981). Crustal structure in the northwestern foothills of the Sierra Nevada from seismic refraction experiments, Bull. Seismol. Soc. Am. 71, 1075-1087.

Steppe, A. J., and C. S. Robert (1978). P-velocity models of the southern Diablo Range, California, from inversion of earthquake and explosion arrival times, Bull. Seismol. Soc. Am. 68, 357-367.

Thurber, C. H. (1983). Earthquake locations and three-dimensional crustal structure in the Coyote Lake area, central California, J. Geophys. Res. 88, 8226-8236.

Thurber, C. H. (1993). Local earthquake tomography: Velocities and $V_{P} / V_{S}$-theory, in Seismic Tomography: Theory and Practice, 
H. M. Iyer and K. Hirahara (Editors), Chapman and Hall, London, $563-583$.

Thurber, C. H., S. R. Atre, and D. Eberhart-Phillips (1995). Threedimensional $V_{p}$ and $V_{P} / V_{S}$ structure at Loma Prieta, California, from local earthquake tomography, Geophys. Res. Lett. 22, 3079-3082.

Thurber, C. H., T. M. Brocher, H. Zhang, and V. E. Langenheim (2007). Three-dimensional $P$ wave velocity model for the San Francisco Bay region, California, J. Geophys. Res. 112, doi 10.1029/ 2006JB004682.

Thurber, C., and D. Eberhart-Phillips (1999). Local earthquake tomography with flexible gridding, Comp. Geosci. 25, 809-818.

Thurber, C., S. Roecker, K. Robers, M. Gold, L. Powell, and K. Rittger (2003). Earthquake locations and three-dimensional fault zone structure along the creeping section of the San Andreas Fault near Parkfield, CA: Preparing for SAFOD, Geophys. Res. Lett. 30, 1112, doi 10.1029/ 2002GL016004.

Thurber, C., S. Roecker, H. Zhang, S. Baher, and W. Ellsworth (2004). Fine-scale structure of the San Andreas Fault zone and location of the SAFOD target earthquakes, Geophys. Res. Lett. 31, doi 10.1029/2003GL019398.

Thurber, C., H. Zhang, T. Brocher, and V. E. Langenheim (2009). Regional three-dimensional seismic velocity model of the crust and uppermost mantle of northern California, J. Geophys. Res. 114, B01304, doi 10.1029/2008JB005766.

Thurber, C. H., H. Zhang, F. Waldhauser, J. Hardebeck, A. Michael, and D. Eberhart-Phillips (2006). Three-dimensional compressional wavespeed model, earthquake relocations, and focal mechanisms for the Parkfield, California, region, Bull. Seismol. Soc. Am. 96, S38-S49.

Waldhauser, F., and W. L. Ellsworth (2000). A double-difference earthquake location algorithm: Method and application to the Northern Hayward Fault, California, Bull. Seismol. Soc. Am. 90, 1353-1368.

Walter, A. W., and W. D. Mooney (1982). Crustal structure of the Diablo and Gabilan Ranges, central California: A reinterpretation of existing data, Bull. Seismol. Soc. Am. 72, 1567-1590.

Warren, D. (1978). Record sections for two seismic refraction profiles in the Gabilan and Diablo Ranges, California, U.S. Geol. Surv. Open-File Rept. 78-340, 95 pp.

Warren, D. H. (1981). Seismic-refraction measurements of crustal structure near Santa Rosa and Ukiah, California, in Research in the GeysersClear Lake geothermal area, northern California, U.S. Geol. Surv. Profess. Pap. 1141, 167-181.

Wessel, P., and W. H. F. Smith (1991). Free software helps map and display data, Eos Trans. AGU 72, 441

Williams, A. J., T. M. Brocher, W. D. Mooney, and A. Boken (1999). Data report for seismic refraction surveys conducted from 1980 to 1982 in the Livermore Valley and the Santa Cruz Mountains, California, U.S. Geol. Surv. Open-File Rept. 99-146, 78 pp.

Yang, Y., M. H. Ritzwoller, F.-C. Lin, M. Moschetti, and N. M. Shapiro (2008). Structure of the crust and uppermost mantle beneath the western United States revealed by ambient noise and earthquake tomography, J. Geophys. Res. 113, B12310, doi 10.1029/ 2008JB005833.
Zhang, H., and C. Thurber (2006). Development and applications of doubledifference seismic tomography, Pure Appl. Geophys. 163, 373-403.

Zhang, H., and C. H. Thurber (2003). Double-difference tomography: The method and its application to the Hayward Fault, California, Bull. Seismol. Soc. Am. 93, 1875-1889.

Zhang, H., and C. H. Thurber (2007). Estimating the model resolution matrix for large seismic tomography problems based on Lanczos bidiagonalization with partial reorthogonalization, Geophys. J. Int. 170, 337-345.

Zhou, H.-W. (2004). Multi-scale tomography for crustal $P$ and $S$ velocities in southern California, Pure Appl. Geophys. 161, 283-302.

Zucca, J. J., G. S. Fuis, B. Milkereit, W. D. Mooney, and R. D. Catchings (1986). Crustal structure of northeastern California, J. Geophys. Res. 91, 7359-7382.

Department of Geoscience

University of Wisconsin-Madison

1215 W. Dayton St.

Madison, Wisconsin 53706

(G.L., C.H.T.)

Department of Earth, Atmospheric, and Planetary Sciences

Massachusetts Institute of Technology

77 Massachusetts Avenue, 54-1818

Cambridge, Massachusetts 02139

(H.Z.)

Seismological Laboratory

California Institute of Technology

1200 E. California Boulevard

Mail Code 252-21

Pasadena, California 91125

(E.H.)

Institute of Geophysics and Planetary Physics

Scripps Institution of Oceanography

University of California, San Diego

La Jolla, California 92093-0225

(P.M.S.)

Lamont-Doherty Earth Observatory

Columbia University

Palisades, New York 10964

(F.W.)

U.S. Geological Survey

345 Middlefield Road, MS 977

Menlo Park, California 94025

(T.M.B., J.H.)

Manuscript received 23 January 2009 